Historic, archived document

Do not assume content reflects current scientific knowledge, policies, or practices. 



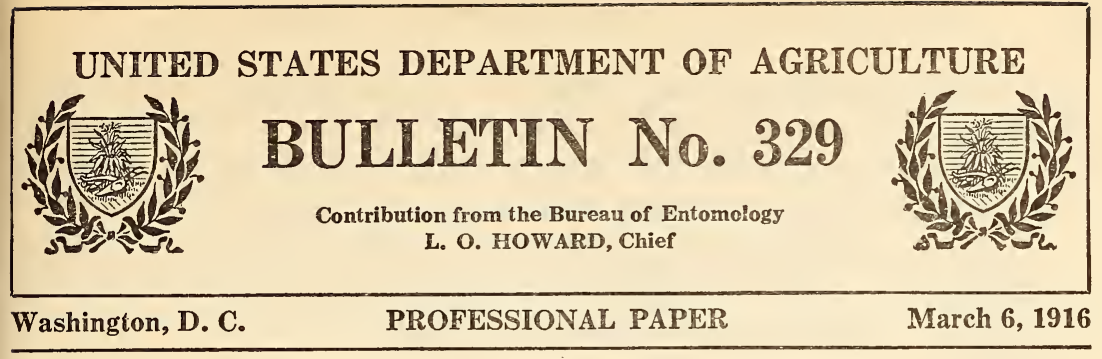

\section{NOTES ON FIVE NORTH AMERICAN BUFFALO GNATS OF THE GENUS SIMULIUM.}

By Arthur W. Jobbins-Pomeroy, ${ }^{1}$ Entomological Assistant.

CONTENTS.

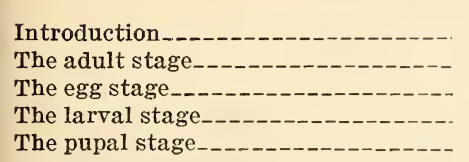

Page.

1
2

11

12

23

\author{
Life cycle and number of generations. \\ Insect enemies and parasites_._._-_- \\ Simulium as a possible carrier of dis- \\ ease \\ Bibliography
}

\section{INTRODUCTION.}

Certain species of the insects known as "buffalo gnats" are important enemies of man and domestic animals in the United States as well as in other countries. Although the principal area of abundance in North America is in Canada and the Northern States, outbreaks of pests of this group occur as far south as Louisiana and Florida. While they are dependent upon running water for development, they make use of very small streams and, to some extent, of irrigation ditches, and are consequently found occasionally in considerable numbers in the drier parts of the country.

About 20 years ago buffalo gnats attracted great attention along the lower Mississippi River. They frequently becarne so abundant that plantation operations were stopped on account of very painful attacks against live stock as well as human beings. These great outbreaks were due to conditions established by the overflow of the Mississippi River. The perfection of the levee system has changed these conditions so that the outbreaks are less frequent and of greatly reduced severity. Nevertheless, these insects are still abundant enough to be considered a pest in the Mississippi Valley as well as in many other portions of the South.

The damage done by buffalo gnats results from their painful bites and the loss of blood which ensues. When they are abundant they 
sometimes cause the death of live stock. At the present time no cases of disease transmission can be attributed definitely to buffalo gnats, but there is a possibility that future investigations will show some important connection with the transmission of diseases.

All of these considerations make it advisable to place on record a considerable number of observations which will serve as a basis for the control of these insects wherever they occur.

The major part of the biological experiments outlined in this paper were carried on at Spartanburg, S. C. The author wishes to express his thanks to Mr. A. H. Jennings, under whose direction the work was done, to the Thompson-McFadden Pellagra Commission for many courtesies receired, and to the directors of the Spartanburg Hospital for the generous way in which they afforded laboratory accommodations and facilities.

\section{THE ADULT STAGE.}

\section{DESCRIPTION OF EXTERNAL ANATOMY.}

The adults of the genus Simulium are usually very small, the largest known North American species (S. pictipes) not measuring more than $4 \mathrm{~mm}$. in length. They are compact in shape, the head being decidedly small in proportion to the rest of the body, and the thorax greatly developed and curiously humped. In some species the thorax and abdomen are very pubescent, in others almost naked. In color the different species vary greatly, ranging from brilliant iridescent yellow and various shades of gray to almost black.

The species of Simulium are holoptic in the male and dichoptic in the female. In the female the facets of the eyes have an equal gradation in size, diminishing somewhat toward the margin. In the male the facets suddenly decrease in size along a line extending on each side from the antennal socket around to the post-genæ, giving the lower portion of the eye the appearance of being divided off by a suture. In color the eyes are usually iridescent bronze in the female and deep iridescent red in the male. Ocelli are wanting in both sexes.

The antennæ are short, moniliform, and 11-segmented. In the species here dealt with the antennæ of the female have the first segment short and cup-shaped. The second is longer, the apical end bearing a chitinous ring which serves as the point of attachment for the third segment, which is nearly the same in length as the second, but pedicellate. The remaining segments are nonpedicellate, broadly joined. Segments 4, 5, 6, 7, 8, and 9 are subequal. The tenth segment is slightly longer. The elerenth is the longest of the entire antenna, narrows to a point at the apical end, and bears from two to three short, strong bristles. The first two segments are minutely pubescent, with a few strong bristles on the apical portion; the re- 
maining segments are densely covered with minute pubescence interspersed thickly with stronger hairs. The antennæ of the male are similar in structure to those of the female, except that they are more slender and have the third segment much longer, twice the length of any of the succeeding segments, and the tenth segment usually the same length as the one immediately preceding it. (Figs. 1 and 2.)

The mouth parts are modified in both sexes into a piercing beak, somewhat similar to that of the Tabanidæ. In the male the organs have become greatly reduced both in strength and armature, so that they are apparently unable to pierce the skin of vertebrates.

\section{DESCRIPTIONS OF INTERNAL ANATOMY.}

Digestive System.

Pl. I, fig. 2.

The following is a description of the digestive organs of Simulium venustum. The diverticulum

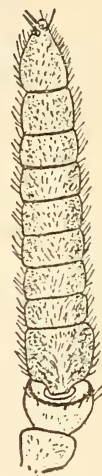

Fig. 1.-Simulium venustum. Antenna of adult female. Greatly enlarged. (Original.) of the oesophagus, or sucking stomach $(v e)$, which is sometimes described as the midintestine or stomach, and whose function seems to be primarily that of a reservoir for blood, is a large membranous bag capable of great distention. At its caudal end it narrows to the constriction known as the pyloric valve $(j p)$. This

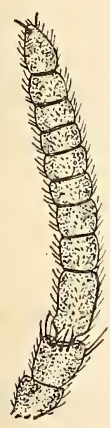

FIG. 2.-Simulium venustum. Antenna of adult male. Greatly enlarged. (Original.) is the place of attachment of the Malpighian tubes.

The Malpighian tubes $(m, m)$, which are greatly developed in this insect, are four in number and are constricted at intervals, with corresponding lobular enlargements. They extend from the base of the diverticulum to its cephalic end, turning again caudad, and ending, as far as can be ascertained, in a small blind nodule. They are opaque white in specimens which have not fed, or specimens dissected on emergence, but show remarkable changes in color at various periods after engorgement. Sometimes they are pink, sometimes rather brownish, and in specimens which have engorged and lived for 40 hours they become checkered brown with transparent intervals.

The ileum (i), which is situated immediately below the pyloric valve, is an elongate, rounded intestine, somewhat curved when in its natural position. The substance which it contains is invariably more solid than that found in the diverticulum, large granules being frequently present. 
Toward its caudal end the ileum narrows into what is probably the colon (c), which leads in turn directly into the sacklike rectum. This is round in shape, transparent, deeply striated, and capable of great contraction and distention. It contains six large oval glands $(r g)$, which are somethat similar to the rectal glands of Stomoxys calcitrans $\mathrm{L}$. At its caudal end the rectum contracts into the external orifice, or anus $(a)$.

Female Reproductive Organs.

Pl. I.

The following is a description of the reproductive organs of the female of Simulium venustum. The two ovaries $(l o$, ro) are situated laterad of the ileum $(i)$. They are small pear-shaped organs, transparent and composed of a thin outer membrane which forms a sack. The interior is filled in newly emerged adults with many small nuclear eggs. (Pl. I, fig. 1.) Joining the ovaries to the diverticulum and the basal membrane of the outer skeleton of the abdomen are large tracheæ, which branch many times, finally ending in thin threads. The caudal end of each ovary narrows into a tubular oriduct $(o d)$. The two oriducts join and form the cephalic end of the tubelike structure known as the utero-ragina $(v)$. The uteroragina and oviducts lie immediately above the lower end of the rectum. Leading from the cephalic end of the utero-ragina on the right side is a very narrow tube which terminates in a round, bulblike structure, black in color, with a transparent membrane. This is the spermathecum $(s)$, whose function is that of a reservoir for the spermatozoa injected by the male at the time of copulation. When an egg is deposited fertilization is effected as the egg passes the orifice in the spermathecum.

Deteloparent of the Eggs.

The stages in the derelopment of the eggs within the ovaries may be described at five different stages, as follows:

First stage.-The eggs are round, rery small, rather transparent. and are present in the ovary in large numbers. As a rule they are rather indistinct. (Pl. I, fig. 1.)

Second stage.-The eggs become denser and generally larger toward the oviduct, more irregular in shape with a tendency toward an oval form. As a rule they are still somewhat indistinct. (Pl. I, fig. 2.)

Third stage.-The eggs are of a perfect oval shape, dense as a rule. and of nearly equal development, those near the oviduct possibly larger. These latter have a tendency toward a slight bulge on one side. The shell has become somewhat denser in appearance, and the eggs on the whole are rery distinct. (Pl. I, fig. 3.) 

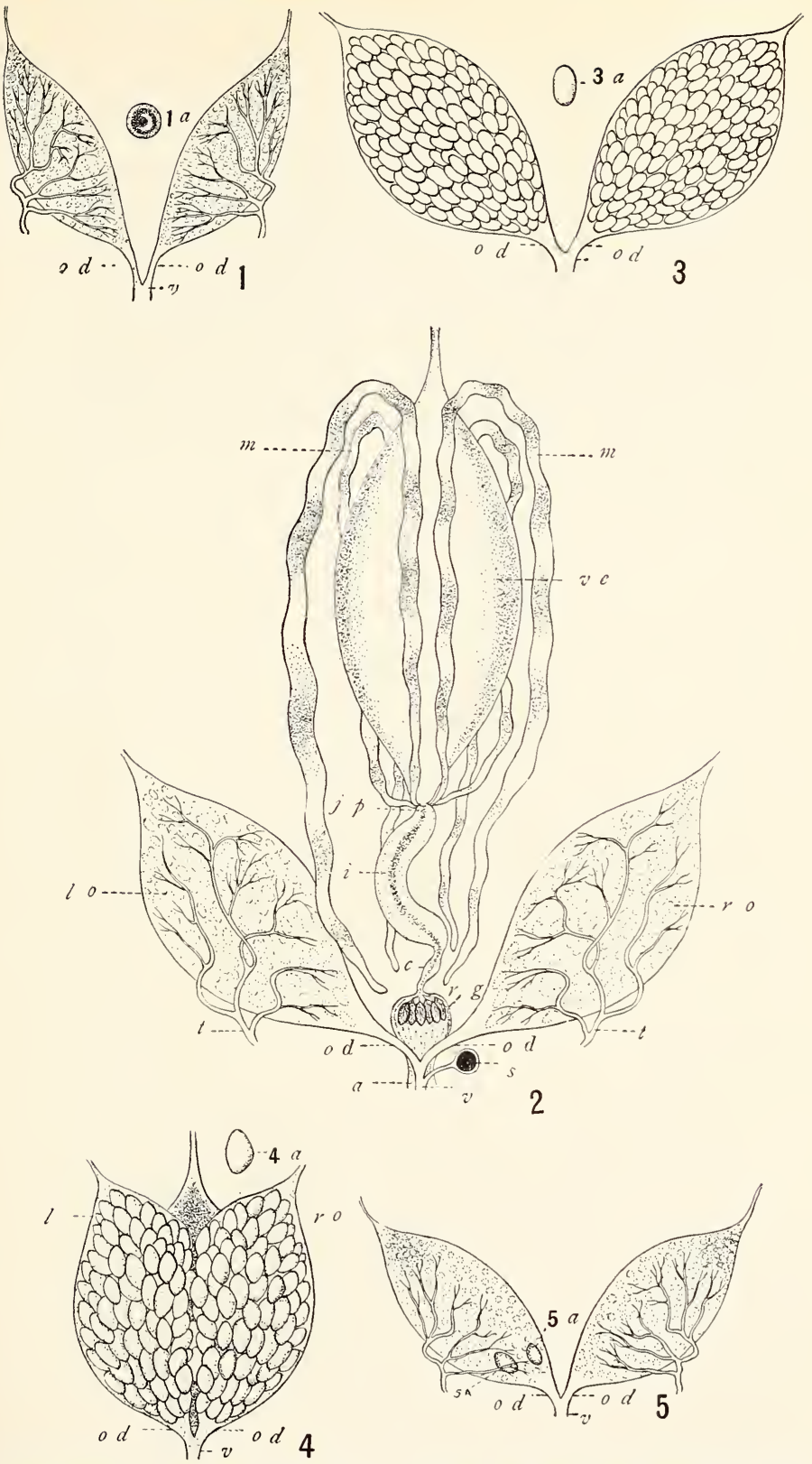

\section{DEVELOPMENT OF EgGS WITHIN THE OVARIES OF SIMULIUM VENUSTUM AFTER} A BLOOD MEAL.

Fig. 1.-Condition of ovaries corresponding to stage 1 (without feeding); $1 a$, single egg from same, larger scale. FIG. 2.-Condition of ovaries corresponding to stage 2 (after blood meal); also internal anatomy of abdomen; ve, ventriculus or stomach; $m, m$, Malpighian tubes; $j p$, juncture of Malpighian tubes and location of pyloric valve; $i$, ileum; $c$, colon; $r g$, rectal glands; od, od, oviducts; $a$, anus; $v$, vagina; $s$, spermathecum; lo, left ovary; ro, right ovary; $t, t$, tracheæ. FIG. 3.-Condition of ovaries corresponding to stage 3 (after blood meal); $3 a$, single egg from same, larger scale. Fig. 4.-Condition of ovaries corresponding to stage 4 (after blood meal); $4 a$, single egg from same, larger scale. FIG. 5. - Condition of ovaries after oviposition; $5 a$, large, fully'developed eggs left near oviducts; remainder of ovary corresponding to stage 1. Highly magnified. (Original.) 

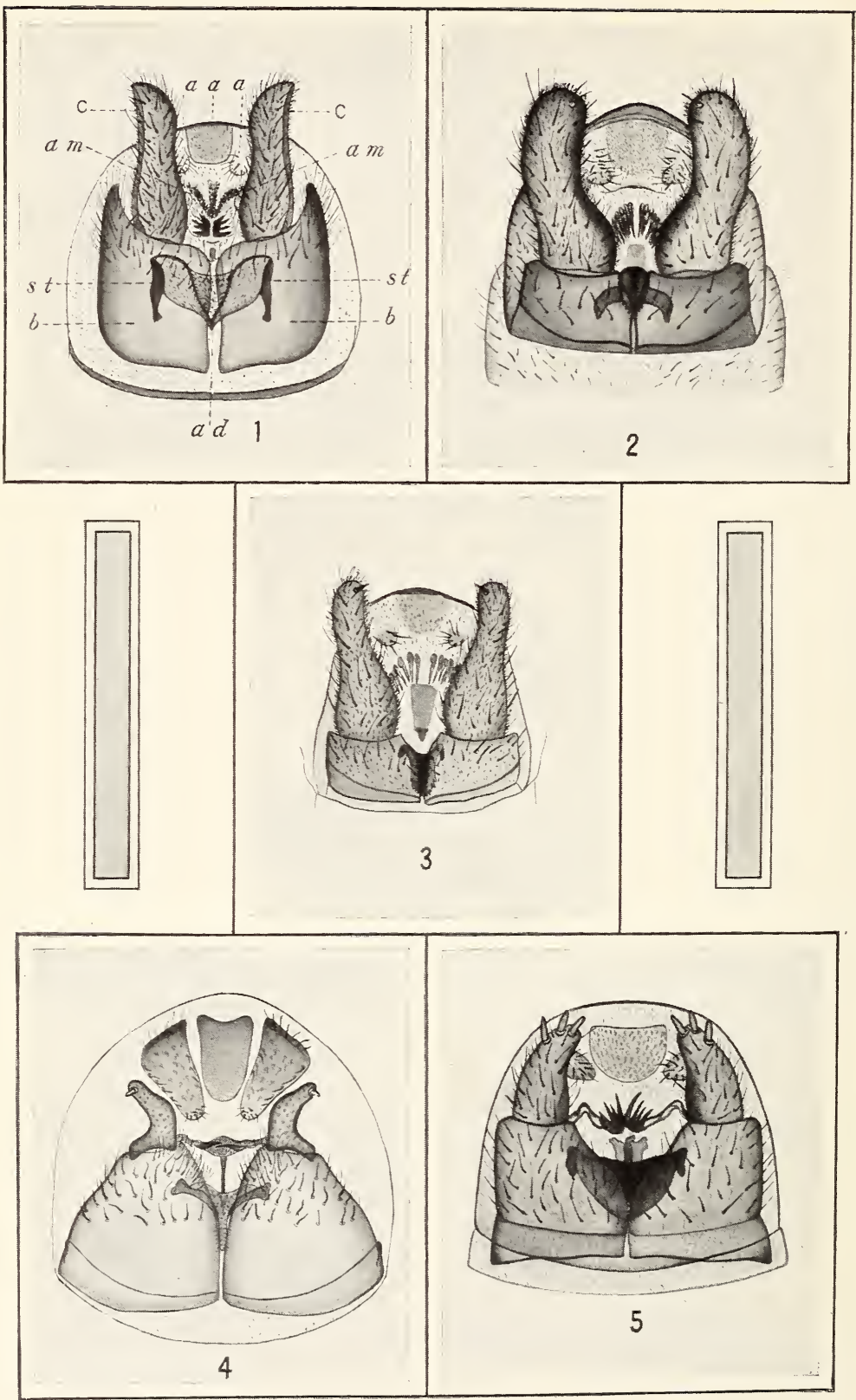

Male Genitalia of Simulium.

FIG. 1-Genitalia of male Simulium pictipes: $c, c$, Claspers; $a, a, a$, anal plates; $a m, a m$, IG. 1.- Gentalia of male arms; $b, b$, basal pieces; st, st, styli; $a d$, adminiculum. Fim jenningsi. FIG. 4.-GeniSimulium venustum. FIG. 3.-Genitalia of male Simulium jenningsi. FiG. 4.-Genitalia of male Simulium bracteatum.
All greatly enlarged. (Original.) 
Fourth stage.-The eggs are fully as large as those newly laid on grass blades, of the same triangular form, very dense, the shell very strong, and not differing from eggs just laid, with the exception that occasionally they may be slightly smaller. (Pl. I, fig. 4.)

Fifth stage.-One or two large eggs are usually left in the ovaries near the oviduct, and the rest of the ovary is entirely filled with the typical round eggs of the first stage. This stage is found after adults have finished ovipositing, and also in specimens taken actually engorging, concerning which more will be said later. (Pl. I, fig. 5.)

The Genitalia of the Male.

P1. II, figs. $1 \div 5$.

The structure of the genitalia of the male shows remarkably constant specific characters. Their systematic value may be seen from the striking differences in the illustration. The determination of the species based on color alone is at best unsatisfactory owing to the amount of variation in individuals of the same species and fading of color in dry mounted specimens. The appearance of the structure of the genitalia does not change when the specimens are preserved in alcohol, and in dried specimens the original shape can be completely restored by the following method:

The last segment of the abdomen of the male after being removed with sharp scalpel or needle is placed in 6 per cent potassium hydroxid (KOH) and left until the soft parts are removed, the chitinous portions remaining intact. The material is then washed with water, run through alcohol in the usual way up to 100 per cent, transferred to xylol, and mounted in balsam, so as to give a direct caudal view as shown in Plate II, figures 1-5. Some of the European species have been studied in regard to the genitalia of the males by Lündstrom, but nothing has been done so far on American species.

The segments to which the organs of the genital armature are attached are collectively designated under the name hypopygium. The most prominent organs of the hypopygium are the two claspers $(c c)$ and the basal pieces to which they are attached. The claspers may be either large, fingerlike, as in $S$. venustum, or greatly reduced and somewhat hook shaped as in S. bracteatum. They sometimes bear a spine at the distal end as in $S$. venustum, a single chitinous fingerlike process as in $S$. bracteatum, or three or four such processes as in S. vittatum. The basal pieces $(b, b)$ to which the claspers are articulated are divided by a suture near the base. They are very large in S. bracteatum and are reduced in S. venustum. The relation between the size of the claspers and basal pieces seems to be very 
constant. If the claspers are large the basal portion is much smaller in proportion, and vice versa.

There are three chitinous plates $(a, a, a$,$) which are situated toward$ the dorsal surface of the hypopygium and surround the anal orifice. The two lateral plates are generally armed with spines or stout hairs.

Ventrad of the plates and extending laterad on each side are two narrow chitinous flanges ( $\mathrm{am}, \mathrm{am}$ ) bearing mesally groups of strong spines, sometimes in a large number as in $S$. venustum and sometimes reduced to only two as in S. bracteatum. These structures have been termed by Lündstrom the "arms." Ventrad of these spines and not easily distinguishable, extending inwardly, is a long, weak, chitinous piece, apparently the sheath of the penis. Ventrad and in front of this piece is a triangular troughlike sclerite called the adminiculum $(a d)$, which is attached to two strong chitinous arms $(s t, s t)$, termed by Lündstrom the stylus.

\section{HABITS OF THE ADULTS.}

\section{Copulation.}

The writer has found adults in copula flying near the stream from which they were emerging, but they at once separated on being disturbed. Dr. Sambon informed the writer that in Italy he has found the males resting on the reeds in swarms, apparently waiting for the females to emerge.

\section{Dispersion.}

It has been stated by several writers that the females travel long distances in search of food, but whether they are prompted by a desire for blood or are involuntarily carried away by the wind is a matter difficult to determine.

The writer has been severely bitten by the females of $S$. johannseni Malloch and S. forbesi Malloch in the sand-dune region of Havana, Ill., at a distance of 5 and even 6 miles from the only possible breeding place, which was the Illinois River. The fact that the adults crossed a bare and sandy waste with little or no wind, and that no males were present, seems to indicate that their flight was voluntary. Riley says that they may be carried 30 or 40 miles. They are sometimes attracted to light, as the writer has found a few specimens flying around a lamp at night.

\section{Feeding Habits.}

The adult female flies of all the species discussed in this paper, with the single exception of $S$. pictipes, ${ }^{1}$ have been frequently observed feeding on the blood of mammals and, so far as the writer

1 One female of this species, fully engorged with blood, was taken from a mule's ear by Mr. A. H. Jennings at Spartanburg, S. C., in 1912. 
has observed, are limited to this diet. There are only two definite records to the writer's knowledge of Simulium feeding upon anything other than the blood of mammals. One is by Hagen (1883), who states that he found Simulium attacking and feeding upon the chrysalids of a butterfly (Pieris) Neophasia menapia Felder. $\mathrm{He}$ does not, however, state the exact species which he found so doing, and remarks that it was similar to the New England "black fly." The other record is by H. Pryer, ${ }^{1}$ who states that in Japan he found Simulium attacking the larva of a sphingid, Smerinthus planus Walk., and also the imago of Stauropus persimitis Butl.

A detailed study was made by the writer in the region of Spartanburg, S. C., of the feeding habits of Simulium venustum, which was found from early spring to late fall engorging within the ears of horses and mules. Though invariably present on these animals, they were seldom found on cattle or on man. The severity of the attacks of this species depend both upon the time of year and the time of day. It is generally believed that the worst attacks occur in early spring and in early fall, and the writer found adults more numerous during the first three weeks of September than they had been since the middle of June. They appear to be most active from $3 \mathrm{p} . \mathrm{m}$. to almost dusk. They are rather easily disturbed while feeding, and unless much distended will struggle violently to disengage themselves from the long hairs in the interior of the mules' ears. It has been noticed repeatedly that even the well-engorged specimens will retract their beaks and successfully fly away and not fall to the ground and crawl away to die, as has heretofore been claimed by certain writers. The fact that they are so easily disturbed and bite only under certain conditions probably accounts for the failure thus far of all efforts to get them to engorge while in captivity. While confined on the human body in a vial they make frantic efforts to escape and after 20 minutes become so exhausted as finally to remain on their backs with scarcely a sign of life. Whether the vial was covered to exclude the light or not, these experiments were unsuccessful at any time of day, both with reared specimens and captured ones. When placed in jars containing cloth saturated with defibrinated cow's blood a few took a small amount of blood into the crop, but there was no distension of the abdomen.

\section{Oviposttion.}

In the method of oviposition the different species of Simulium, whose life history has been studied in detail, show characteristic adaptations according to their habitat, and may be classified arbitrarily into two distinct groups. Although this grouping applies clearly to conditions in South Carolina, it is possible that exceptions may be found in other regions. 
GROUP 1.

Group 1 contains species normally restricted to rivers which have rocky beds and such obstructions as bridge piles, piers, and, in time of floods, partly submerged trees. These species deposit their eggs at the level of the water, or just below, on any convenient surface, such as the bare portions of rocks, sunken posts, and collections of water-worn débris, always where the current is exceedingly swift. Eggs have never been found by the writer on any surface that was not smooth or that was at all covered by moss, algæ, or other aquatic growths. Of the five species whose methods of oviposition are discussed in this article, $S$. pictipes alone belongs in this group. The oviposition and early life history of this species rere first described by Dr. W. S. Barnard in the American Entomologist in 1880 . He states that the eggs are long ovoid in form, and gives a figure showing them deposited in a vertical position. He also states that the young larvæ were issuing from the eggs deposited on the rocks above the water line and were passing down into the water to begin aquatic life. If this was the case, the eggs must have been moistened continually by the spray and not left in a dry state, as is implied, the reason for which surmise will be discussed at length farther on.

The eggs of this species which were found by the writer seemed to have been deposited indiscriminately in a horizontal as well as in a vertical position. The angles appeared rather broadly rounded. (Pl. III, fig. 6.) Surrounded by a viscous substance known as the matrix, in which they are fairly evenly distributed, they are laid normally in masses on the smooth surface of the rocks just below the level of the water. The matrix is brownish yellow at first, afterwards turning brown. Usually several females will oviposit in the same spot, causing the layers to overlap.

GROUP 2.

Group 2 is made up of species which are peculiar to small streams with less force of current and with only submerged herbage or occasional small collections of sticks and stones to serve as a place for the attachment of the immature stages. As a general rule the situation selected for oviposition is a grass blade bent at right angles and trailing just at the surface of the water and with its surface continuously moistened.

$S$. vittatum almost invariably oviposits on grass blades in small streams. The eggs adhere to the grass blades by a creamy viscous matrix entirely covering the eggs. This matrix turns yellowish brown on the second day and becomes gradually darker until the eggs hatch. The eggs are laid in a single layer, as a rule, very closely together. Several females often select the same situation and, as in the case of pictipes, the layers often overlap one another. 
At Dallas, Tex., in March, 1913, S. vittatum was found by the writer ovipositing in considerable numbers on the small stones in the limestone bed of a small stream which was almost devoid of submerged herbage. The eggs were laid generally below or at the surface of the water. In a few instances they were found an inch or so above the water, but this was owing to a decrease in the amount of water, which varies considerably in this and the majority of streams in Texas. This species has been found by the writer on one occasion at Havana, Ill, ovipositing in large numbers on the bridge piles in the Illinois River. The eggs were deposited at or just below the level of the water, and as the river was falling at the time at the rate of an inch a day, the eggs underwent complete desiccation, and all were destroyed. The bridge piles were literally covered with the matrix and eggs, and many females, becoming entangled, died adhering to the viscous masses. This oviposition of this species in the main river seems to have been an abnormal occurrence, as the larvæ have never been found in this situation. Another species, however, $S$. johannseni, according to the writer's observations, breeds in enormous numbers in the main channel in the spring, around the submerged vegetation near the banks and wherever there is an obstruction.

$S$. venustum, in the regions studied, belongs entirely to group 2. The eggs are laid on submerged grass blades and the like in small streams, in situations similar to those selected by S. vittatum. The eggs are more evenly arranged than those of that species, the matrix is not smeared so profusely, and the egg mass is generally oblong in shape and very compact. This species has many times been observed ovipositing, and specimens which subsequently laid a full quota of eggs in captivity were taken from the stream as they alighted.

The oviposition in captivity of $S$. venustum was observed by the writer at Spartanburg, S. C., on September 16, 1913. A female S. venustum was noticed at $5.08 \mathrm{p}$. m. moving up and down a small stream within a space of about 4 feet, apparently seeking a suitable place for oviposition. She would touch the water for an instant and then, apparently dissatisfied, fly up again. This peculiar interrupted flight was continued for a period of two minutes, after which she alighted on a grass blade which seemed to be satisfactory. Immediately a bottle was placed over her and she was at once taken to the laboratory. The stream from which the specimen was taken was situated 50 yards from the laboratory, and thus little time was lost in transit. The bottle in which the specimen was taken was partly wet inside. At 5.13 p. m., as soon as the bottle was placed on its side, she felt around for two minutes and then settled into position, rapidly thrust out the end of her abdomen, and deposited an 10981 $1^{\circ}$ Bull. 329-16-_-2 
egg about every two seconds, as fast as she could extend and retract her ovipositor. Ten eggs were laid in a sort of half circle and then the intervening space was filled up until each egg touched another. In addition a few were laid a short distance away and the intervening space filled up. Oviposition continued steadily until 5.20 p. m., when she stopped, turned around, felt the mass with her feet, and commenced again. She stopped at 5.21 for 30 seconds and cleaned the end of her abdomen. Another lot of eggs was then laid a little farther off, in a long, irregular row, about five eggs wide. Oviposition was finally ended at $5.27 .30 \mathrm{p} . \mathrm{m}$.

She seemed always to feel for a suitable place before ovipositing. A dry spot was invariably rejected. One hundred and forty-five eggs were laid from 5.15 to 5.20, about 80 eggs from 5.20 to 5.21 (this seemed to be the maximum rate of oviposition), and about 117 from 5.21 to 5.27.30. The total number of eggs laid was 349. As there were two interruptions, one at 5.20 for three seconds and one at 5.21 for 30 seconds, the length of time spent in oviposition was 12 minutes. The average rate at which the eggs were laid, therefore, was about one every two seconds.

The abdomen was dissected, and only one developed egg was found. This was in the oviduct, showing that the oviposition was normal, as all developed eggs, with this exception, had been deposited.

$S$. bracteatum seems to be entirely restricted to the smaller streams, and its method of oviposition is similar to that of $S$. venustum in all respects. It is of the same size as venustum and deposits about the same number of eggs at one oviposition.

$S$. jenningsi is so closely allied to $S$. venustum that it is extremely difficult to distinguish the egg masses of the two species, the main points of difference being the smaller size of the S. jenningsi mass and the somewhat smaller number of eggs that are deposited.

The time of day generally chosen for oviposition by these five species of Simulium is from about $4.30 \mathrm{p} . \mathrm{m}$. to $5.30 \mathrm{p}$. m., or even until dusk. The weather conditions most favorable seem to be sunshine and lack of wind. Females have been found ovipositing at a maximum water temperature of about $95^{\circ} \mathrm{F}$. The earliest records of oviposition were made by the writer at Dallas, Tex. (latitude $32^{\circ}$ $4^{\prime} 8^{\prime \prime}$ ), on March 25, and the latest at Spartanburg, S. C. (latitude $\left.34^{\circ} 50^{\prime \prime}\right)$, on November 2.

There have been various estimates given by authors, both in Europe and America, upon the number of eggs laid by Simulium. The number of eggs stated to have been laid, or probably laid at one oviposition by a single female, varies from 500 to 1,500. This latter figure, given for the European species S. reptans L. ( $S$. columba- 
schense Fab.), is probably erroneous, as the species is very like $S$. venustum in size and structure. It is the opinion of the writer, from many observations, that the largest possible number of eggs which are deposited at one time by a single female can not exceed 500 .

The question whether eggs of Simulium can be subjected to desiccation and then hatch after being immersed again in water is of interest, as it has been suggested that in the more or less torrential streams found in Texas and the Western States, which flow only a few months in the year, the eggs might remain in a dry condition during the summer and hatch in the fall or spring with the rising of the water. For this reason experiments have been made by the writer to ascertain whether Simulium eggs, after partial or complete desiccation, would hatch on being again placed in water, as is the case with some species of mosquitoes. These experiments all showed that at Spartanburg, S. C., the contents of freshly laid eggs became completely disintegrated after being thoroughly dried, and that when the eggs contained embryos, the latter became distorted on the second day after removal from the water, and though they were replaced in running water after that period the contents of all finally disintegrated without a single egg hatching.

When eggs are found at any distance above the water line, the writer believes investigation will show that a fall in the water level has occurred. The great outbreaks of Simulium in the large rivers during the early spring are due primarily to the fact that the rising water submerges the growth on the banks and that the water either rises or remains at the same level throughout that period, thus preventing desiccation of the eggs.

\section{THE EGG STAGE.}

The eggs of Simulium are usually rather triangular in shape, with the angles broadly rounded. (Pl. III, figs. 1-5.) The egg of $S$. pictipes (Pl. III, fig. 6), however, is more ovoid in shape than that of the four other species dealt with in this paper. The shell, which is very tough and apparently somewhat chitinous, withstands the action of the water for a considerable period without disintegrating, and has been found by the writer in a good state of preservation after six weeks in this element.

The color of the egg when first laid (Pl. III, fig. 1) is opaque white, which changes to yellowish brown as the development of the embryo proceeds. The interior of the newly laid egg appears to be an even mass of yolk substance. When the egg contains a half-developed embryo the yolk substance seems to be consolidated into a central mass, indented at both extremities and surrounded by layers of 
closely arranged cells (Pl. III, fig. 2). The interior of an egg containing an embryo three-fourths dereloped has a peculiar banded appearance (Pl. III, figs. 3, 4), but as the time of hatching approaches the most noticeable features are the cephalic eye spots on the embryonic larva, which become more and more distinct. (Pl. III, fig. 5.) Detailed studies on the embryology of Simulium have been made by Mecznikow, ${ }^{1}$ Kölliker, ${ }^{1}$ and Graber. ${ }^{1}$

The average period of incubation, from June to October, of the species studied by the writer at Spartanburg, S. C., was about 8.8 days; the minimum period, 7 days; and the maxium, 12 days. The following table will show the normal variation in that region from June to October:

Table showing period of incubation of eggs of Simulium. ${ }^{a}$

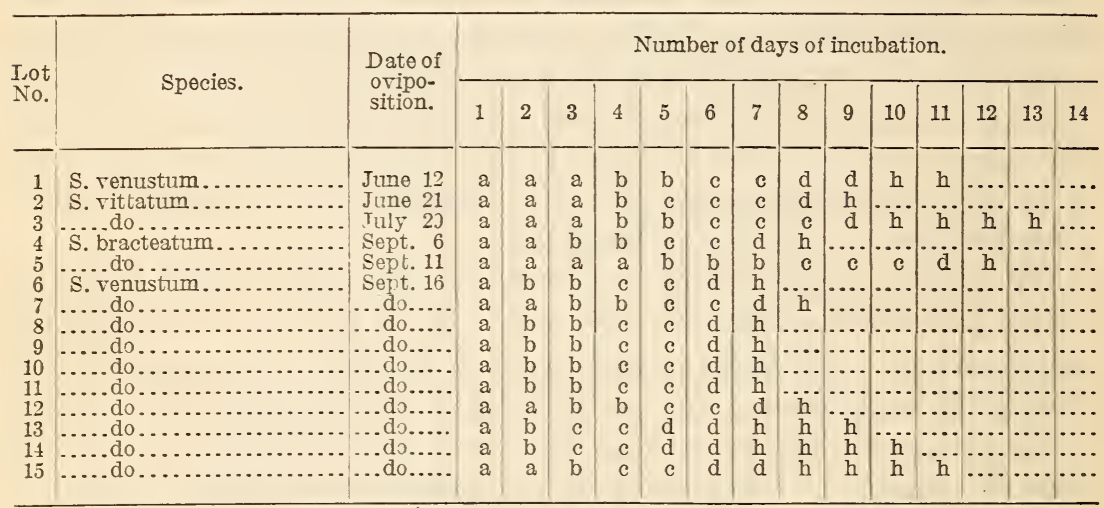

$a$ Letters indicate stage of incubation, shown on Plate I, as follows: a, corresponds to fig. 1 ; $b$, corresponds to fig. 2 ; c, corresponds to figs. 3,4 ; d, corresponds to fig. 5 ; $h$, date of hatching.

The eggs seem to hatch equally well in either still or running water. The percentage of eggs that hatch is very high when they are placed so that the water reaches them, the arerage sterility of a series of lots kept under observation in normal conditions being from 4 to 5 per cent. The approximate percentage of egg masses, however, that is deposited under such favorable conditions is certainly relatively small as compared with the total number deposited, and the location of the egg mass seems to be the dominant factor in determining the successful hatching of the larra and the consequent abundance of the insect.

\section{THE LARVAL STAGE.}

The larvæ of the known species of Simulium, as will be discussed at length farther on, are invariably aquatic in their habits and re- 

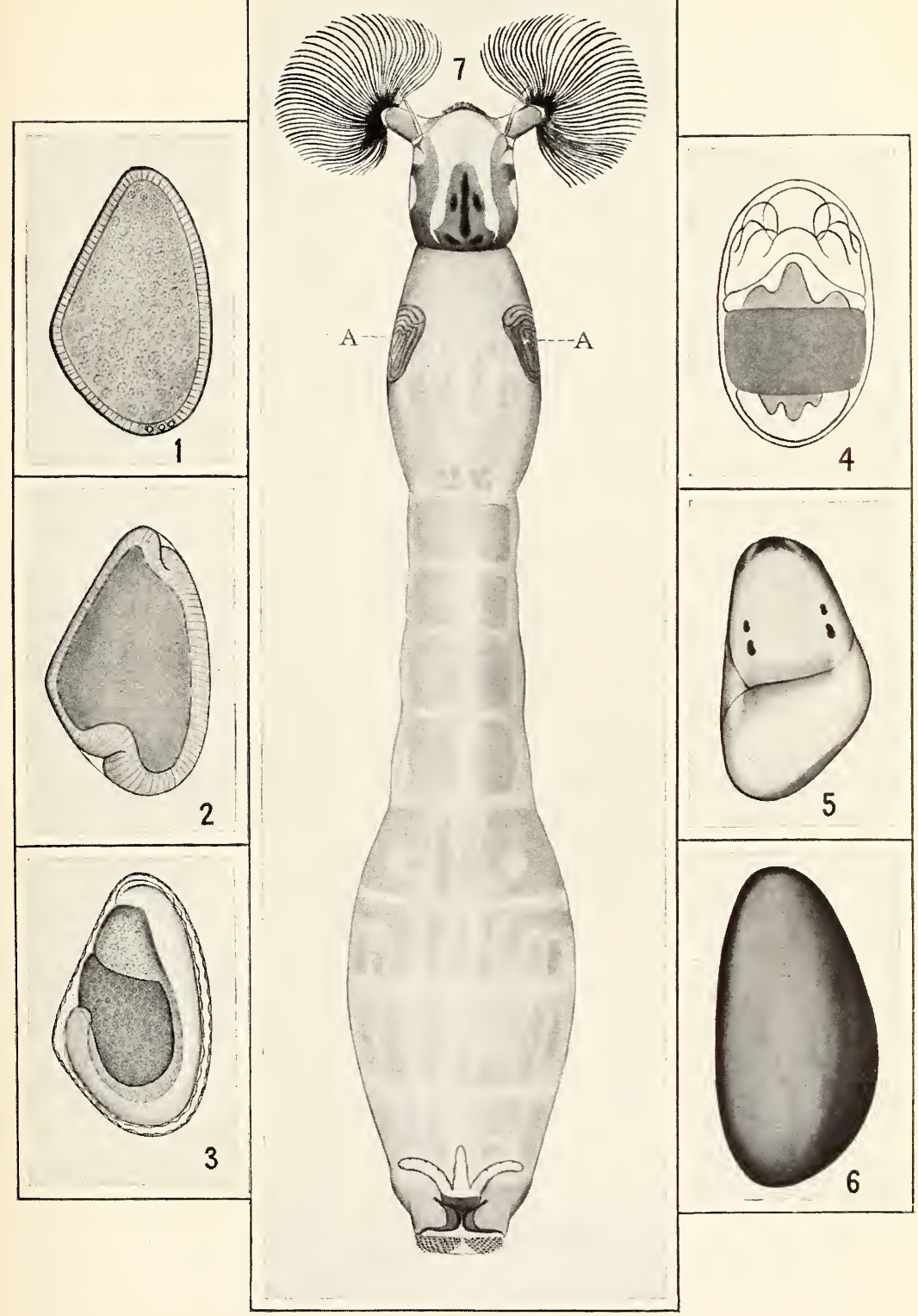

\section{EGGS AND LARVA OF SIMULIUM.}

FIg. 1.-Egg of Simulium venustum, freshly laid. (After Mecznicow.) Frg. 2.-Egg of Simulium venustum, second to fourth day. (After Mecznicow.) FIG. 3.-Egg of Simulium venustum, fourth to sixth day, showing "banded appearance." (After Mecznicow.) FIG. 4.Same, dorsal view. (After Kölliker.) Frg. 5.-Egg of Simulium venustum, just before hatching, showing larva in a free condition within the shell. (Original.) FIG.6.-Egg of Simulium pictipes. (Original.) Frg. 7.-Larva of Simulium bracteatum, showing histoblasts of pupal filaments, A, A. All greatly enlarged. (Original.) 


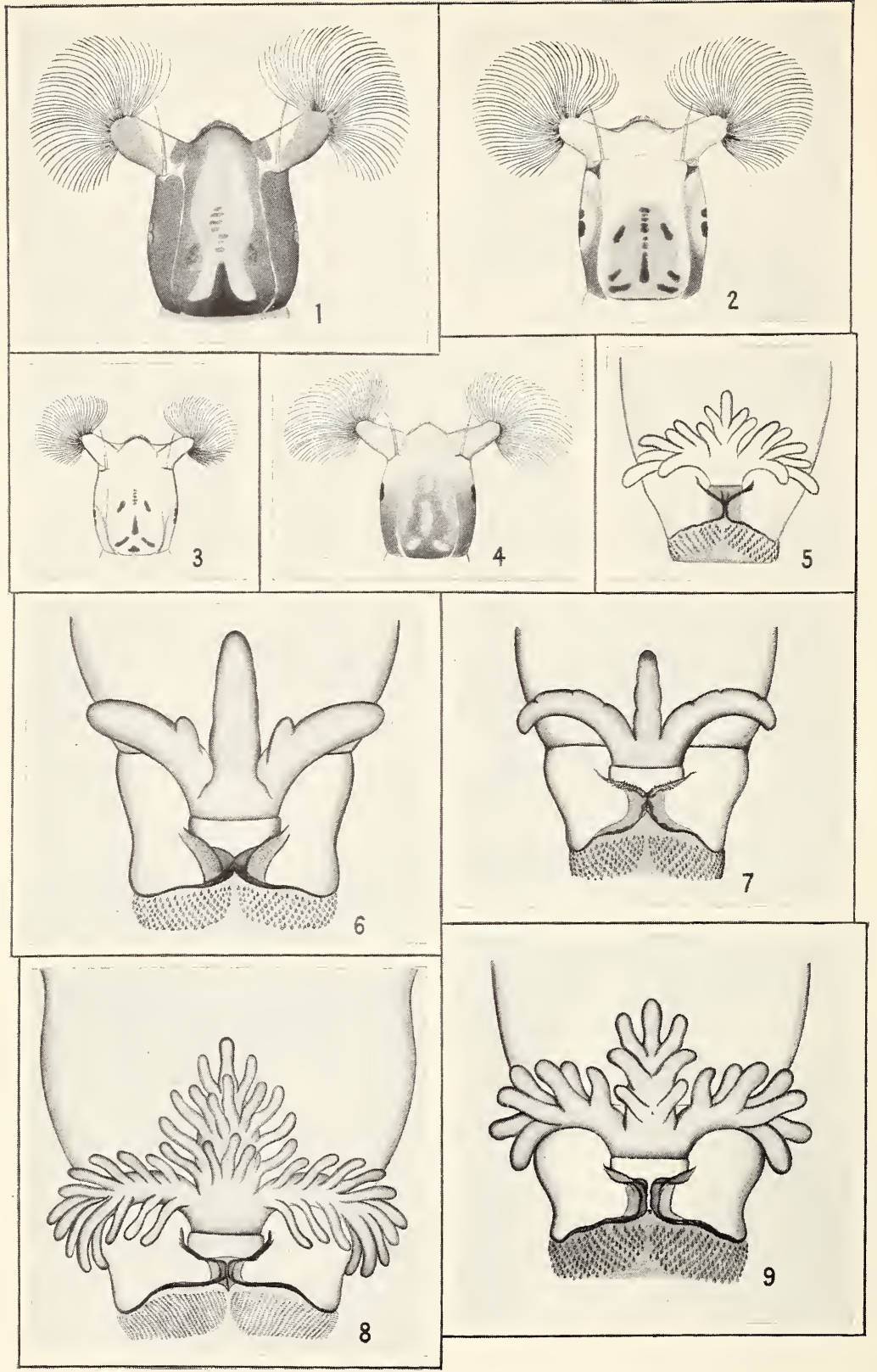

Heads and Rectal Gills of Simulium Larvfe.

FIG. 1.-Head of larva of Simulium pictipes. FIG. 2.-Head of larva of Simulium vittatum. FIG. 3.- Head of larva of Simulium jenningsi. FIG. 4.-Head of larva of Simulium venustum. FIG. 5.-Rectal gills of larva of Simulium jenningsi, typical form. FIG. 6.-Rectal gills of larva of Simulium vittatum, variety with small lobes at base. FIG. 7.-Rectal gills of larva of Simulium bracteatum, typical form. FIG. 8.-Rectal gills of larva of Simulium pictipes, typical form. FIG. 9.-Rectal gills of larva of Simulium venustum, typical form. All greatly enlarged. (Original.) 
quire swiftly flowing water for their development. The full-grown larva of the largest species, according to Johannsen, measures not more than $15 \mathrm{~mm}$. in length. The American species known to the writer measure from $12 \mathrm{~mm}$. ( $S$. pictipes) to $3.5 \mathrm{~mm}$. (S. jenningsi). The larvæ are generally subcylindrical, somewhat attenuated at the middle, and with a gradual dilation toward the anal extremity. In addition to the head there are 12 rather indistinct body segments.

In the larval stage the shape and number of the branches of the rectal gills seem to be good systematic characters, not differing essentially among individuals of the same species. If the number and

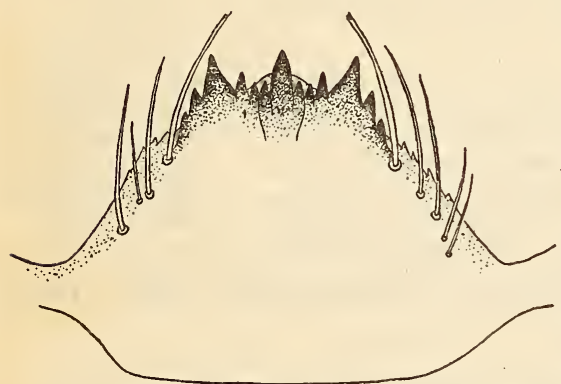

FIG. 4.-Simulium bracteatum. Labial plate of larva. Greatly enlarged. (Original.) length of the antennal joints, the teeth in the mentum, and the character of the dorsal markings of the head are also used, the determination of $\mathrm{h}$ alf - $\mathrm{g}$ r o w $\mathrm{n}$

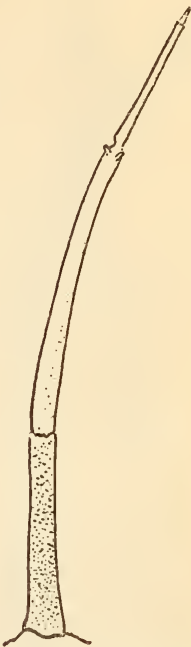

FIG. 3.-Simulium bracteatum. Antenna of larva. Greatly enlarged. (Original.) larvæ is possible. The larvæ in their last stage can be correlated positively with their respective pupæ by the dissection and study of the pupal filaments, which become fully developed under the larval skin.

As the larvæ of $S$. bracteatum and $S$. jenningsi have not been previously described, the following descriptions are given.

DESCRIPTION OF LARVA OF SIMULIUM BRACTEATUM.

The full-grown larva is from 6 to $6.5 \mathrm{~mm}$. in length. The general color varies from light yellowishbrown to grayish, with conspicuous brownish markings on the ventral surface. The antennæ (fig. 3) are slender, 4-segmented $;^{1}$ the second segment one and one-half times as

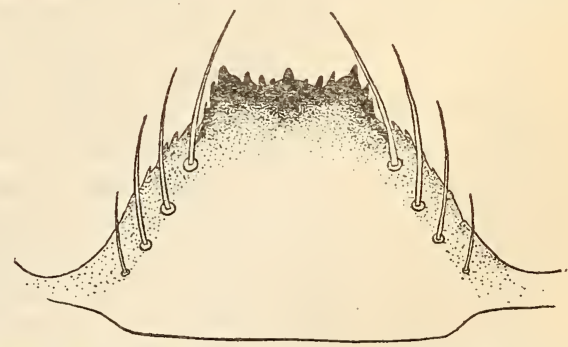

FIG. 5.-Simulium venustum. Labial plate of larva. Greatly enlarged. (Original.) long as the first; the third segment as long as the first; the fourth a short conical process; the general color pale hyaline; the first segment infuscate.

The labial plate (fig. 4) is more strongly serrate than that of S. venustum (fig. 5): the apical margin rather convex; the middle tooth and each corner tooth very large. There are from four to five long bristles near the lateral margin on each side.

1 The writer differs from other writers in regard to the segmentation of the antennæ. 
The head (Pl. III, fig. 7) is light brownish-yellow in color, heavily marked with brown on the lateral margins. The dorsal markings of the head are ar-

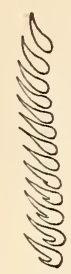

FIG. 6.-Simulium bracteatum. Row of spines from $c$ a u d a 1 sucker of larva. Greatly enlarged. (Original.) ranged in the form of a long central irregular blotch, with two adjacent blotches extending diagonally on either side.

The mandibles are similar to those of S. venustum (fig. 12), but darker in color. The maxillæ are infuscate and rery hairy ; the proximal portion of the maxillary palpus is dark brown, with a few sparse hairs ; the distal end transparent, bearing a few conical processes.

The rectal gills (Pl. IV, fig. 7) are simple, three branched, somewhat pointed toward the distal end, and are curved backward cephalically when extended.

The caudal sucker bears from 60 to 70 rows of spines or hooks (fig. 6).

The larvæ were taken by the writer from sereral streams in the vicinity of Spartanburg, S. C., from June to October, 1913. They were separated from the larvæ of other species by the number of the branches of the pupal filaments (formed under-

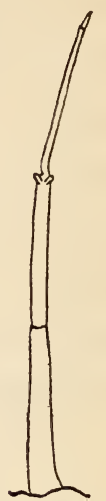

FIG. 7.-Simulium je $n n i n g s i$. A n ten na of larva. Greatly enlarged. (Original.) neath the larval skin) and determined from adults reared from them and compared with the type.

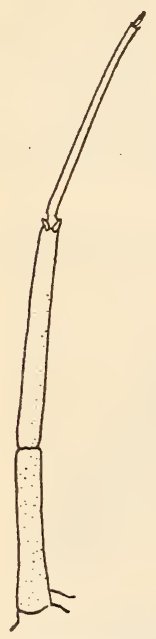

FIG. 8.-Simulium venustum. Antenna of larra. Greatly enlarged. (Original.)

\section{DESCRIPTION OF THE LARVA OF SIMULIUM JENNIXGSI.}

The larva of simulium jenningsi is much smaller than that of $S$. venustum and measures from 3.5 to $4.5 \mathrm{~mm}$. in length. The general color is light brownish yellow. The head is of a uniform yellow with dark-brown blotches of characteristic arrangement on its dorsal surface (Pl. IV, fig. 3), thus differing from venustum (Pl. IV, fig. 4), which usually has the pigment in these cells lacking. The antennæ (fig. 7) are slender and 4-segmented, the last segment being a short conical process; the first three segments are subequal in this species, while the antennæ of venustum (fig. 8) have the second segment longer than the first. The labial plate (fig. 9) is broader than that of venustum (fig. 5) the teeth more eren and equal in size, the middle tooth not very prominent, and there are apparently only two large and one small bristle along

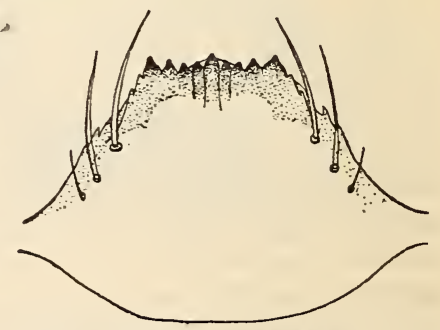

Fig. 9.-Simulium jenningsi. Labial plate of larra. Greatly enlarged. (Original.)

each margin, while venustum has four to five large bristles on each side.

The mandibles are of the usual type, but rather weak and the teeth somewhat pale. 
The rectal gills (Pl. IV, fig. 5) are three-branched, each lateral branch bearing six lobes and the middle branch five, as a rule. This is a smaller number of lobes than is found in venustum (Pl. IV, fig. 9), which has seven or eight on each lateral branch.

The caudal sucker bears from 70 to 75 rows of hooks.

The larvæ were taken by the writer from a fairsized stream near Spartanburg, S. C., in August, 1913, and were separated from the larvæ of other species by the number of branches of the pupal filaments (formed underneath the larval skin) and determined from adults reared from them and compared with the type.

\section{EXTERNAL AND INTERNAL STRUCTURES OF THE LARV}

The head is more or less quadrangular in shape and very chitinous. The eyes have become reduced to mere pigment cells, in the shape of two irregular black blotches, situated on each side of the head.

In addition to the usual mouth parts, the head bears a pair of peculiar fan-like organs, situated one on each side at the anterior end. The rays or cilia of the fans are attached at

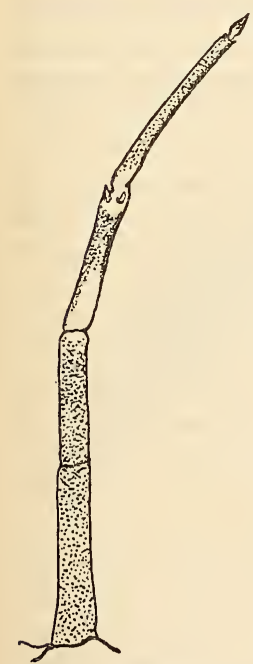

FIG. 11.-Simulium vittatum. Antenna of larva. Greatly e n larged. ( O rig inal.) the base each by a strong peduncle and range in number from 30 to 60 according to the species. On the inner margin of these cilia are

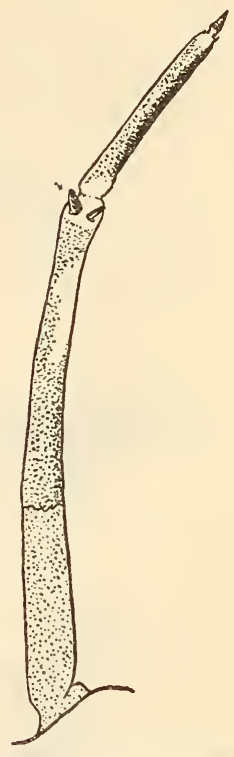

FIG. 10.-Simulium pictipes. Antenna of larra. Greatly en larged. ( $\mathrm{O} \mathrm{rig} \mathrm{-}$ inal.) fringes of short hairs interspersed with minute teeth. As the number of cilia varies in individuals of the same species, they are not very reliable specific characters. The fans, acting as strainers, catch the microorganisms on which the larvæ feed and sweep them into the mouth.

The antennæ (figs. 3, 7, 8, 10, 11) are situated at the sides of the head, on the dorsal surface toward the cephalic end, just below the base of the fans. They are slender, and in the species examined, naked. Johannsen says "The antennæ are apparently jointed *** the first joint twice as long as the others taken together; the second, slender cylindric *** the third joint a short pointed process at the apex of the second." Miall says "Small three-jointed antennæ" and gives a figure in which the antennæ have three long joints and lack the short pointed process forming the last joint. Of the five species dealt with in this paper, the larvæ of Simutium venustum (fig. 8), S. pictipes (fig. 10), and S. bracteatum (fig. 3) 
have the antennæ 4-jointed, the first long joint described by Johannsen being divided by a very distinct suture. Though the first and second joints are very closely articulated and rigid, the constant occurrence of a distinct suture between them seems to indicate clearly the existence of two segments. The third segment is slender cylindrical, and the fourth a short conical process.

There are two conical processes situated at the apical end of the second segment, which seem to be sense organs. The antennæ of $S$. vittatum (fig. 11) are 5-segmented, the second segment being again divided. The sense organs are borne on the apical end of the third

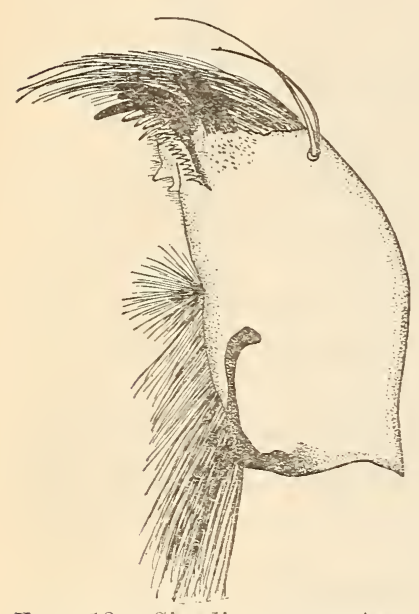

FIg. 12.-Simulium venustum. Left mandible of larva, ventral view. Greatly enlarged. (Original.) segment. In color the antennæ vary with the species from yellowish hyaline to dark brown.

The mandibles are situated just below the fans and more horizontally. With the exception of a slight difference in size, according to the species, there are no constant characters of real systematic value in the mandibles.

The following is a description of the mandibles of $S$. venustum:

The mandibles (fig. 12) are very chitinous, stout, somewhat elongate, with the outer lateral margin rounded. There are from two to four large teeth at the apex on the inner lateral margin, almost dense black in color. Situated immediately dorsad along the inner margin of the largest tooth is a row of from six to eight smaller teeth of the same shape, but much lighter in color and gradually decreasing in size. Behind this row, on the ventral surface of the mandible, arising generally from the third or fourth tooth, is a second row of small, sharp-pointed teeth very pale in color, about 10 to 14 in number, which continues along the basal portion of the lateral margin of the largest apical tooth. Laterad of this second row of teeth, on the inner margin of the mandibles, there is a large wide-angled flattened tooth, very pale in color, followed by a smaller one of the same description. Near the apex of the mandible, a short distance from the outer lateral margin of the rentral surface, are two large bristles arising from almost the same point. At the base of the large apical teeth, on the ventral surface, are two clumps of stout hairs. There is a fringe of long hairs on the dorsal surface of the mandible, which extends halfway down, commencing at the apex, where it almost obscures the apical teeth. Opposite the base of this fringe on the inner lateral margin of the mandible there is a fan of long hairs, and a fringe of very long hairs, which continues down to the base, gradually developing into bristles explanate and divided at apex.

The maxillæ are situated immediately ventrad and mesad of the mandibles. The maxillary palpus is short, cylindrical, and bears on its distal end several small cone-shaped protuberances similar to 
those borne on the third segment of the antenna. The lacinia bears mesad and cephalad fringes of long hairs and bristles. On its distal end there is a single spurlike process.

The labrum is short, rounded, fringed with long hairs, and is situated overhanging the hypopharynx. It is reinforced on its dorsal surface by a strong $\mathrm{T}$-shaped. sclerite. The apical margin is sometimes serrate.

The labium (figs. 4, 5, $9,13,14)$, which almost covers the ventral surface of the hypopharynx, is composed of two or more broad chitinous united plates. It is immovable. The apical edge of the ventral plate is serrate.

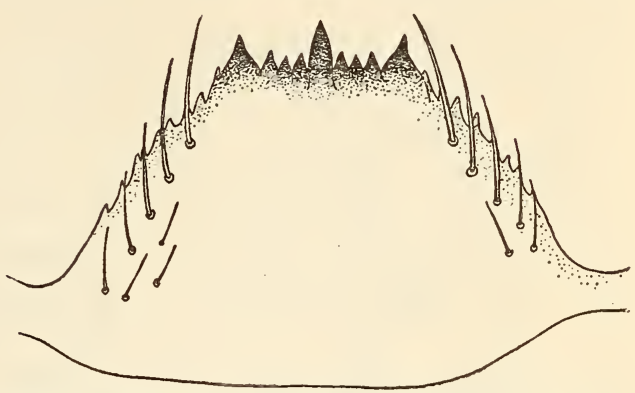

FIG. 13.-Simulium vittatum. Labial plate of larva. Greatly enlarged. (Original.)

The lateral and apical margins of the dorsal plate are also serrate and the apical margin usually bears a very prominent central tooth. In some species the teeth are trifid, and in others simple. There is a row of from three to 10 long bristles near each lateral margin of the ventral plate. The number and shape of the teeth and the arrangement of the bristles are of systematic value in separating the different species, and Robaud and Malloch ${ }^{1}$ consider these char-

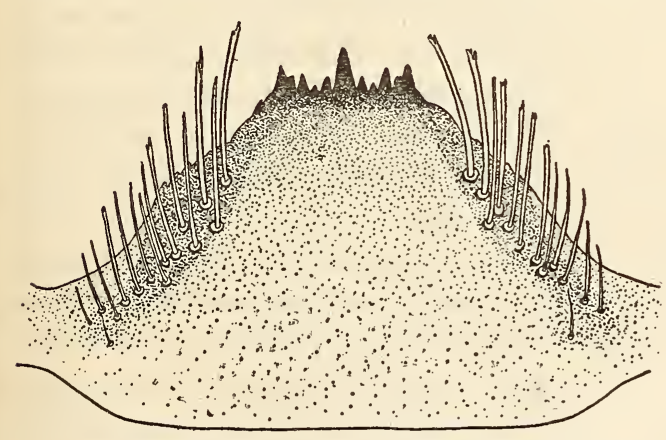

Frg. 14.-Simulium pictipes. Labial plate of larva. Greatly enlarged. (Original.) acters to be of possible generic value. There is a certain amount of individual variation, but seemingly within definite limitations.

The dorsai portion of the head in most species has distinct markings of very characteristic arrangement. (Pl. IV, figs. 1-4.) Though subject to a certain amount of individual variation, they are of systematic value in separating the different species especially when combined with other more constant specific characters. These markings are formed by a collection of large cuticular cells which, in some species, such as S. vittatum, are strongly pigmented, while in others, such as $S$. venustum, they are normally almost devoid of pigment, the surrounding area being dark.

${ }^{1}$ Malloch, J. R. American black files or buffalo gnats. U. S. Dept. Agr. Bur. Ent. Tech. Ser. no. 26, 71 p. (p. 8), 6 pl., 1914.

$10981^{\circ}-$ Bull. $329-16-3$ 


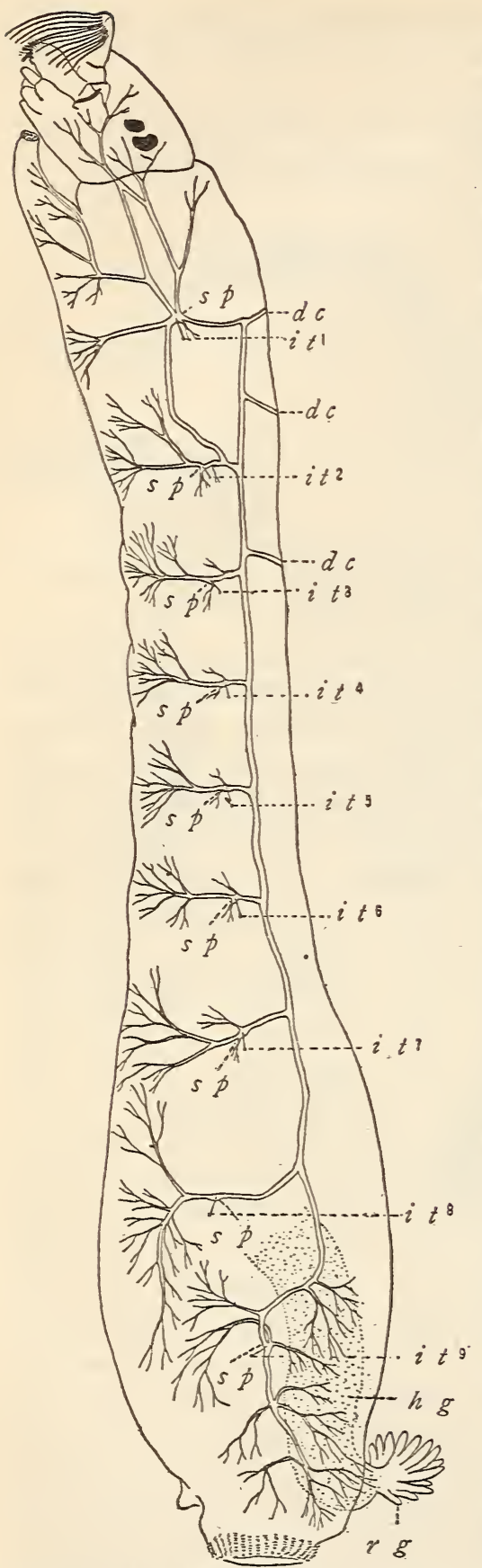

FIG. 15.-Simulium venustum. Tracheal system of larva : $d c, d c, d c$, Dorsal commissures; $i t$, initial threads; $s p(9)$, spiracular chambers; $h g$, hind gut; $r g$, rectal gills. Greatly enlarged. (Original.)
The thoracic proleg of Simulium larræ consists of a single elongated, truncate process, attached to the second thoracic segment and bearing concentric rows of minute hooks at its apical end, which is cup-shaped, and capable of muscular contraction, thus forming a suckerlike organ, used by the larra as means of attaching itself. A somewhat similar but rery much larger suckerlike disk is situated at the caudal extremity of the larra. The rim is composed of rows of strong chitinous hooks as in the proleg. The number of rows ranges in the different species from 50 to 140 , and the number of hooks in a row from 8 to 30 . There is so much individual variation in the number of rows and the number of hooks in a row that they are not of much systematic value. The a verage number of rows in the caudal disks of five species is as follows: $S$. jenningsi, from 70 to $75 ; S$. venustum, from 55 to $6 \check{5}$; $S$. bracteatum, from 60 to $70 ; S$. vittatum, from 65 to 85 ; S. pictipes, from 130 to 140 . S. pictipes has by far the greatest number of rows, very close together and from 25 to 30 hooks in each row. It is the only one of these fire species that can be positively determined on these characters alone.

\section{RESPIRATORY SYSTEM OF THE LARVA.}

The tracheal system of the larra (fig. 15) consists of two main longitudinal trunks, connected by commissures, which lead to the spiracular chamber. Extending from the spiracular chambers are thin chitinous rods (the initial threads), which lead to the oval 
thickenings of the cuticle known as the spiracles. The spiracles do not seem to be functional as a means of respiration.

Respiration apparently takes place by what are known as the rectal gills (Pl. I, fig. $2, r g$ ), which are extensions of the rectal wall and are formed of the same epithelial layer. These extensions are primarily 3-branched, and are either simple or bear numerous lobes. Minute tracheolæ penetrate these gills, joining the main trunks at the base of the rectum. The gills are also filled with blood, are retractile into the rectum, but are usually extended in running water. According to Headlee, they function both as blood gills and as tracheal gills, as the presence of blood in them is undoubted, and since the tracheæ in them are very minute. The tracheal system can be seen very distinctly in living larvæ. Several larvæ, still quite active, were placed in a shallow dish of water and examined under the binocular by the aid of strong sunlight against a black background. As the larvæ slowly died the trachex, owing to the air collected in them, showed a bright silvery appearance, so that even the very small ramifications and branches could be clearly distinguished. The larvæ seem to be in a comatose condition an hour or so before death, and the silvery appearance of the tracheæ remains for about three hours after death, so that there is a considerable period in which the trachex may be studied before the air is driven out. In larvæ preserved in alcohol or mounted in balsam the air, of course, is driven out of the tracheæ, which becomes almost transparent, so that it is very difficult to trace them in this condition. The tracher become greatly ramified toward the caudal end of the body and seem to penetrate the wall of the alimentary tract and to extend into the rectal gills.

Larvæ have not been found to survive longer than forty-eight hours in still water, and on being transferred from flowing water will turn back constantly in an effort to clean the rectal gills with the mouth parts. Larvæ placed in still water and only barely covered will survive longer than those covered to a depth of 3 inches or more. That the lack of oxygen is responsible for the death of the larvæ transferred from flowing to still water is further evidenced by the fact that the larvæ will survive longer in a tightly corked bottle at a temperature of $32^{\circ} \mathrm{F}$. than at a temperature of $75^{\circ} \mathrm{F}$., because the amount of oxygen that can be held in solution by the water varies inversely as the temperature. Larvæ seem to thrive equally well in running water, whether the temperature is $32^{\circ}$ or $75^{\circ} \mathrm{F}$. Low temperature seems to retard but not to injure development, and a rising temperature up to $75^{\circ} \mathrm{F}$. hastens development.

The structure of the rectal gills and the number of lobes afford excellent systematic and specific characters, as may be seen from the accompanying figures (Pl. IV, figs. 5-9). The variation in individuals seems to be bounded by well-defined limitations. 


\section{LARVAL DEVELOPMENT.}

From 12 to 16 hours before hatching the young larvæ are in an apparently free condition within the shell. There is an almost continual movement of the head, which is forced against the ectoderm by sudden convulsive movements of the body. The shell suddenly splits and the larva at once emerges, literally tumbling out. The split reaches from the cephalic end of the egg to the middle, generally a little to the left. It is evident from the clear appearance of the alimentary tract of the newly emerged larva that the ectoderm is not eaten away at all. The larva at once clings to the nearest point of attachment by its thoracic proleg and waves its anal portion around several times, evidently to clear the rectal gills. It then attaches itself to the nearest object by the peculiar suckerlike organ on its anal extremity and thrusts out its gills at intervals of about 15 seconds. It at once commences to feed on the matrix surrounding the eggs and the adjacent microorganisms, using its thoracic proleg as a scoop, with a constant movement of this organ toward the mouth parts. In still water the fans are not used for sweeping in the food for some hours after the larvæ have hatched, but remain appressed to the sides of the head.

The newly hatched larvæ of all the species described in this paper measure from two-thirds to three-fourths of a millimeter in length. The structure of the larvæ in the first instar, of the species examined by the writer, is fundamentally the same as in the last, with the exception that the head is larger in proportion to the rest of the body and the general appearance very transparent, due to the lack of pigmentation and the empty condition of the alimentary tract. The black eye spots on the sides of the head are very prominent, and the dorsal markings of the head, though not so distinct as in later stages, are easily distinguishable. The silk glands are employed almost at once after hatching to form a silken thread, which is used to hold the larva in position in the current. The structure of the rectal gills seems to remain the same throughout larval development.

\section{LARVAL HABITS.}

\section{MOLTING OF THE LARVA.}

According to Strickland ${ }^{1}$ the larvæ do not shed the entire skins but only the skeleton of the head. The writer has found that the entire skin is shed, as larvæ have been found which had partly cast off the entire skins, bearing the chitinous hooks of the caudal sucker, and which showed the caudal sucker again developed in the new larval skin. The entire skeleton of the head is cast off toward the

${ }^{1}$ Strickland, E. H. Some parasites of Simulium larvæ and their effects on the development of the host. (In Biol. Bul., v. 21, no. 5, p. 302-338 (p. 303), 5 pl., Boston, 1911. 
front at molting, and the remainder of the skin toward the caudal extremity, the tracheæ being withdrawn through the spiracular openings. The number of molts has not been determined.

\section{MIGRATORY HABITS AND LOCOMOTION OF THE LARVAE.}

On being suddenly disturbed or on the diminishing of the current, the larvæ let themselves be carried down stream steadied by the silken thread previously described, which they have attached to some stationary object, and seek a more favorable situation. In many instances the larvæ have been observed almost to regain their former position, by winding up the thread with the thoracic proleg and mouth parts, but as a rule they are unable to work against the current. The method of locomotion in still water is similar to that of geometrid larvæ. By looping the body, they bring the anal extremity forward beside the proleg, which is then released on the caudal sucker again obtaining a firm hold.

A heavy rain causing a sudden swiftening of the current will often entirely change the distribution of the larvæ. This fact is of considerable economic importance, as it may account for the sudden appearance of Simulium in localities usually exempt. This was well illustrated in the following instance, observed by the writer at Spartanburg, S. C. A fair-sized stream had been free from larvæ for two months or more, when one of the tributaries near its source became heavily infested with young and half-grown larvæ. A heavy rain and consequent washout carried practically every larva from the tributary down the large stream for nearly a mile, where they became successfully established, causing a subsequent heavy infestation.

Young larvæ seem to migrate more readily than full-grown larvæ. Several experiments were tried in regard to this. A vessel containing larvæ of all sizes was placed under a running faucet, causing the vessel to overflow. The full-grown larvæ as a rule remained in the comparatively still water within the vessel, often spinning their cocoons and successfully pupating. The young and half-grown larvæ seemed invariably to detach themselves and would be found within two hours gathered on the surface over which the water was flowing.

At one time the attention of fish culturists was drawn to Simulium, as the larvæ were stated to cause the death of young trout by entangling them in a silken web. This was disproved in the American Entomologist and Botanist, in 1870, by Mrs. Sarah J. McBride, ${ }^{1}$ who clearly demonstrated that the "death web of young trout" was a myth, and that the threads were not strong enough, or interwoven, so that fish could be entangled in them. 
THE FOOD OF THE LARVA.

The food of the larvæ is entirely microscopic. There are various accounts given on this subject by different authors, and they are somewhat divergent. Riley says that they feed on animalcules, but do not disregard microscopic matter of vegetable origin. $\mathrm{He}$ also states that larvæ kept in a jar were seen to swallow the minute larval forms of small crustaceans belonging to the Copepoda and Isopoda, and that a number of square diatoms, joined together in chains, were found in the alimentary tract.

Miall says that he has found in the alimentary tract flinty valves of diatoms, desmids, and pieces of small crustaceans.

Kellogg, in his article on the food of Simulium and Blepharocera, states that he found thousands of tiny siliceous shells of diatoms in the intestines. They caused considerable difficulty in the making of microscopical sections for histological study. He also states that the larvæ feed on the stalked Gomphonema and occasionally on the genus Nitzschia. They are also stated to feed on Vaucheria and Nothrix.

The writer has found that the color of the larva varies according to the nature of the stream, and that the larva seem to thrive best in streams containing the largest proportion of such organisms as Euglena viridis and Spirogyra. Larvæ in running water were observed feeding in specially constructed glass tanks, and were seen to reject large Paramoecia and apparently anything except the smallest particles of the plankton. A striking fact seemed to be the effect of different foods upon the color of the larvæ. When the tank containing the food of the larvæ was filled only with water, decaying vegetable matter, and living grasses, the larvæ became emaciated and starved to death; but on the introduction of green algæ and Spirogyra, they regained their vitality and the alimentary tract changed from a light brownish yellow to a bright green. Dissections of the alimentary tract showed normally a quantity of green rod-like algæe, flinty shells of diatoms, and some minute star-shaped animalculæ. The larva of Simulium pictipes, which lives in the larger streams, has the alimentary canal filled with a quantity of sand; and the color is always brown corresponding to the brown growths on the rocks. The streams in South Carolina, which were contaminated by chemical refuse from the cotton mills, were absolutely free from larva, and this fact is of economic importance as it may be utilized further in the control of the larvæ. Pure animal sewage is not deleterious to the growth of the larvæ, provided the other environmental factors are favorable. 


\section{THE PUPAL STAGE.}

METHODS OF PUPATION.

The histoblasts of the pupal and adult organs are formed in Simulium larvæ some considerable time before pupation takes place, and can be discerned when the larvæ are half grown, shortly after the second molt. The pupal respiratory organs, composed of long tubelike filaments (Pl. V, fig. 1), can be seen underneath the larval skin, on the sides of the anterior portion of the thorax, lying coiled up and visible as rounded darkened areas which become almost black as the pupal stage approaches. (Pl. III, fig. 7, A, A.) Shortly after the molt preceding pupation the chitinous hooks on the dorsal and ventral surfaces of the abdomen of the pupa become well developed underneath the larval skin.

Before commencing to pupate the larva spins over itself a pocketshaped pupal case, formed of the strong silken threads supplied by the salivary glands. The shape and texture of the pupal cases vary according to the species. Of the five species discussed in this paper, four have pupal cases of the shape that may be described as the "wall-pocket" type, the texture finely spun, almost leathery in appearance, the cases being spun as a rule well separated from one another, and the distal end wide and rather open. (Pl. V, fig. 2.) $S$. pictipes is the exception, having the pupal case shaped after the fashion of a boot (Pl. V, fig. 5), the heel always pointing downstream, the pupal cases often overlapping one another in a corallike formation, the texture coarsely spun, very tough, and the distal end narrow.

Shortly before the larva has finished making the pupal case the air from the tracheæ, entering the extension leading from the base of the main trunk from which the branch filaments arise, slowly creeps along the entire length of the filaments. The skin splits along the dorsum of the thorax and the filaments are at once projected into the water. The skin behind the head is then worked off toward the caudal end of the larva and the old tracheæ are withdrawn through the spiracular openings. The inner lining of the hind gut, together with the anal gills, which are formed of the same epithelial layer, is then cast out through the anal slit which is situated just above the $\mathrm{X}$-shaped sclerites on the dorsal surface at the posterior end of the larva, and may be seen attached in the interior of the cast larval skin, which often remains for a while within the pupal case. The skeleton of the head of the larva is then pushed off downward to the front, the wall of the alimentary canal, about as far as the junction of the pharynx and the œsophagus, coming away with it. The pupa seems to lock itself in the pupal case by means of the 
strong hooks on the dorsal and ventral surfaces of the abdomen. These hooks are turned anteriorly on the dorsal surface on segments 2,3 , and 4 ; posteriorly on the dorsal surface of segments 7,8 , and 9 , and all hooks on the ventral surface are turned anteriorly. The whole operation of pupation and of spinning the pupal case takes from 45 minutes to 1 hour.

\section{GENERAL DESCRIPTION.}

The pupæ of Simulium at first are generally golden yellow or light brown, the color and shape of the adult organs showing very clearly through the pupal skin as the time of emergence approaches. There are nine abdominal segments. On each side of the thorax are situated the respiratory organs, composed of long chitinous tubes, arising from a main stalk, tapering somewhat, and usually branching dichotomously toward the distal end. The number of filaments, always counting the branches of the distal ends, varies according to the species, from 4 to 60 , and is an excellent systematic character, as it is very constant for each species. On the dorsal and ventral surfaces of the abdomen are situated rows of strong chitinous hooks. These seem to be of little use as distinguishing characters for the five species discussed in this paper, as they are approximately the same in number and have about the same position in each. The pupæ can be positively correlated with the adults by the dissection of mature male pupæ and study of the genitalia.

The pupæ of $S$. bracteatum and $S$. jenningsi have not been previously described, and the following descriptions are given:

\section{DESCRIPTION OF PUPA OF SIMULIUM JENNINGSI.}

The pupa of S. jenningsi (Pl. V, fig. 4) is not more than $2.5 \mathrm{~mm}$. in length, and is golden yellow when first formed.

The respiratory filaments, which are situated at each side of the thorax near the head, are each composed of a single main trunk, which divides at base into the following branches: Four single unbranched filaments and two long filaments, each of which divides again dichotomously, making eight branches in all, counting the distal ends of the branches.

On the dorsal surface of the abdomen there is a row of very small hooks on each side of the second segment, and on the third and fourth segments rows of four very large hooks on each side pointing cephalad. On the fifth segment there is a row of hooks pointing caudad, and on the ninth segment a row of minute hooks near the cephalic margin and a single large hook on each side at the middle of the segment. On the ventral surface of the abdomen there are two large hooks close together on the fifth segment, and two large hooks, rather far apart, on each of the sixth and seventh segments. The caudal end of the pupa is cleft for a short distance in the middle.

The pupæ studied were reared from larvæ and determined from adults reared from them and compared with the type. 


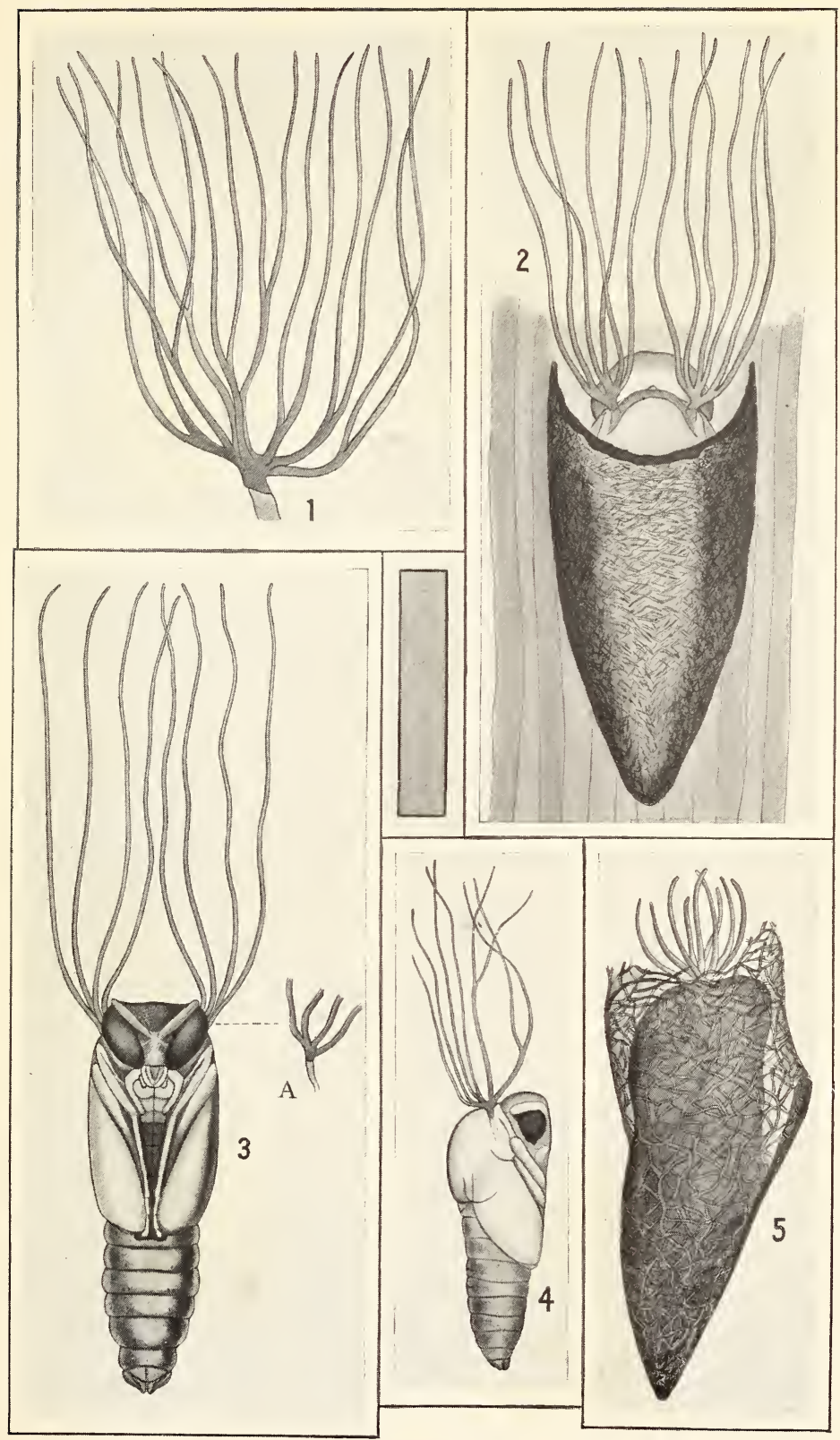

PUPA OF SiMULIUM.

FIG. 1.-Respiratory filaments of pupa of Simulium vittatum. FIG. 2,-Pupa of Simulium venustum, in pupal case. FIG. 3.-Pupa of Simulium bracteatum: A, side view of filaments. FIG. 4.-Pipa of Simulium jenningsi. FIG. 5.-Pupa of Simulium pictipes, in pupal case. All greatly enlarged. (Original.) 

DESCRIPTION OF PUPA OF SIMULIUM BRACTEATUM.

The pupa of S. bracteatum (Pl. IV, fig. 3) measures about $4 \mathrm{~mm}$. in length and is of a golden yellow color when first formed.

The respiratory filaments are composed of a single main trunk on either side of the thorax, each of which divides in the following manner: Two long branches arise from the base of the main trunk, which again divides a short distance farther up, making four long branches on each side, counting the branches at the distal ends. The hooks on the abdomen are arranged as usual.

The pupæ were reared from larvæ and determined from adults reared from them and compared with the type.

\section{DURATION OF PUPAL STAGE.}

The duration of the pupal stage of $S$. venustum, according to Mrs. Sarah J. McBride, at Mumford, N. Y., is three weeks. The maximum period in the pupal stage of the same species observed by the writer was nine days at Havana, Ill., late in the fall, the average temperature during that period being $36^{\circ} \mathrm{F}$.

The minimum period in the pupal stage of $S$. venustum was a little over 84 hours at Spartanburg, S. C., during the month of June, with a temperature from $70^{\circ}$ to $90^{\circ} \mathrm{F}$. The average length of the pupal period for the five species under consideration, during the summer, is from five to seven days.

The general effect of low temperature seems to be to retard, and of rising temperature up to $90^{\circ} \mathrm{F}$. to hasten the emergence of the adult from the pupa. The effect that low air temperature has on the pupa in retarding development is much less in proportion than the effect that a rising temperature between $60^{\circ}$ and $80^{\circ} \mathrm{F}$. has in hastening emergence. Though their structure is normally adapted for aquatic life, yet when they are exposed to the air, as sometimes happens when the water falls, they will often emerge even after 24 hours spent out of water if the adult is sufficiently developed within the pupal skin. This was especially noticeable at Havana, Ill., in 1912, when the river began to fall.

The respiratory system of the pupa is a modification of the general tracheal system of the larva. The rectal gills having been cast off, their function appears to be assumed by the tubelike filaments arising on each side of the thorax. There are two long main trunks extending down each side of the abdomen. These give off branch tracheæ, connected by commissures, which lead to the abdominal spiracular chambers, from which arise the initial threads leading to the spiracles. The spiracles are cuticular invaginations and become closed, according to Taylor, ${ }^{1}$ on the withdrawal of the old tracher at the time of the

1 Taylor, T. H. On the tracheal system of Simulium. In Trans. Ent. Soc. London, $f$. 1902, p. 701-716 (p. 703), 8 fig., 1902. 
shedding of the larval skin. From the mesothoracic spiracular chamber extends a broad tracheal trunk leading to the base of the main trunk of the respiratory filaments, which do not contain tracheæ, but are hollow. According to Taylor, ${ }^{1}$ the air is not taken directly into the gill base from this hollow space, but is absorbed through the external chitinous fibrillæ and thence into the tracheal extension through a membrane.

\section{EMERGENCE FROM THE PUPAL STAGE.}

Four or five hours before emergence there is a very noticeable intermittent movement of the adult within the pupal skin, which is gradually distended with air toward the anal extremity, the abdominal tracheæ being probably withdrawn through the spiracular openings. Coincident with this the anal portion of the adult is withdrawn from the pupal skin and a threadlike membrane, seemingly the lining of the hind intestine, may often be seen extending from the anus of the adult to the pupal skin, to which it remains attached after emergence. As the pupal skin is locked by the strong chitinous hooks to the pupal case, the adult exerts a strong pressure toward the cephalic end and the pupal skin splits along the dorsal portion of the thorax and head, forming a T-shaped aperture. The adult at once rises to the surface of the water surrounded by a bubble of air which has been collected in the distended pupal skin, and running along the surface of the water at once takes flight. The curious way in which the adult rises to the surface surrounded by a bubble was commented on by the earliest writers on the group, and in situations where the pupæ are found in thousands, as in parts of Hungary, and along the Illinois and Mississippi Rivers in America, the water seems almost to boil as they emerge.

\section{LIFE CYCLE AND NUMBER OF GENERATIONS.}

The number of generations varies according to the species and the latitude. In the Southern States the species seem to breed continuously from about the middle of March until the approach of severe cold weather, generally about the end of November. The life cycle of one generation during the summer takes approximately four weeks; 7 days in the egg stage, 17 days as larvæ, and 4 days as pupæ. The time from the egg to the adult stage varies according to the rise and fall of the temperature. There are probably from five to six generations annually in South Carolina of the species here dealt with, except $S$. pictipes, which normally has three generations. In Illinois there are only three or four generations of $S$. venustum annually. 


\section{INSECT ENEMIES AND PARASITES.}

The larvæ of Simulium are often parasitized by nematode worms of the genus Mermis, specimens of which have been found by the writer measuring $12 \mathrm{~mm}$. in length. These were found in larvæ of $S$. venustum, coiled around the intestines, and extended from near the caudal end to the thorax. The specimens that attained the greatest length were found singly, but as many as four have been found in individual larvæ. According to Strickland (1911), ${ }^{1}$ the Mermis retard the development of the pupal and adult histoblasts, cause the death of the larvæ, and escape through punctures made in the epidermis. He also states that in the vicinity of Boston, Mass., Mermis was found parasitizing larvæ only during the spring, and that there is a seasonal variation of parasitism. The writer, while in South Carolina, found species of Mermis parasitizing larvæ from May until late in October, and these larvæ seemed to have developed the pupal histoblasts to a much greater extent than is estimated by Strickland. The larvæ are also heavily attacked by glugeid and gregarine species of Myxosporidia.

The writer has found the larvæ being attacked by species of Hydropsyche in Illinois and South Carolina. Dr. Howard (1888) ${ }^{1}$ also mentions this fact in his article on a species of Simulium at Ithaca, N. Y., and gives a fuller account in the Annual Report of the U. S. Commissioner of A griculture for 1886, page 510. Species of minnows attack the larvæ frequently, and Riley ${ }^{2}$ mentions that the small fishes of the family Cyprinidx also feed on them.

The pupæ, so far as is known, are not parasitized by Mermis or Myxosporidia. The adults have been found by the writer at Spartanburg, S. C., to be frequently parasitized by nematode worms of the genus Mermis, which were usually found singly. In one instance three of the worms were found in a female $S$. venustum. The same number were found in a female of $S$. bracteatum. They were situated in the abdomen, coiled around the Malpighian tubes and intestines, and in some cases extended into the thoracic region. The vitality of these specimens infested by the Mermis seemed to be seriously affected, though they lived for some time, 31 hours being the minimum and 72 the maximum period. All of these specimens thus parasitized were reared from pupæ, with the exception of on adult female of $S$. bracteatum, which was taken flying around a lamp at night. No adults taken biting on animals were ever found to contain Mermis.

\footnotetext{
1 See Bibliography, p. 35.

${ }^{2}$ Riley, C. V. Report of the Entomologist. In Rept. U. S. Comr. Agr. f. 1886, p. 459592 (p. 510), 11 pl., 1886.
} 
Georgewitch ${ }^{1}$ describes a trypanosome, Crithidia simutiae, which he found in the stomachs of adult females taken biting cattle, etc. The locality in which the animals were attacked was a district in Servia, and the species $S$. reptans (=S. columbaschense). $\mathrm{He}$ did not, howerer, find any similar organism in the blood of the animals attacked.

Riley ${ }^{2}$ states that Lugger observed them being attacked by Asilidæ and Odonata.

Wise $(1911)^{3}$ reports that in British Guiana the adult females of Simulium are attacked by a roracious enemy in the nature of a black and white wasp (probably Monedula signata), which follows the aboriginal Indian to obtain the "Pium" (Simulium). This wasp reduces the "Pium" to unconsciousness, deposits eggs, and leaves the body to be fed upon by the resulting larræ.

\section{SIMULIUM AS A POSSIBLE CARRIER OF DISEASE.}

In $1874 \mathrm{~J} . \mathrm{P}$. Megnin ${ }^{4}$ strongly adranced a theory that two species of Simulium in the Department of the Rhone, France, are the transmitting agents of virulent charbon. He also mentions Stomoxys and Haematobia in this connection, but places most emphasis on Simulium, whose habits more closely conform to the outbreaks and distribution of the disease in that locality. He also states that, in his opinion, M. Tisserant, sent by the French Gorernment to inrestigate the subject, prored that Simulium was the cause or the transmitting agent of the disease. In a later paper he reaffirms his statements and mentions that he has found a "Psoriasis guttata" prevalent in the ears of horses, and belieres it is due to the bites of Simulium. The writer has found a similar condition to be very common in the ears of horses, undoubtedly due to the bites of Simulium, in Illinois, South Carolina, and the vicinity of Washington, D. C. As this condition may be of a purely secondary nature, and as apparently no experimental or careful analytical work has been done on the subject, all statements regarding the transmission of a disease of cattle by Simulium must be regarded as purely theoretical.

According to Riley and other authors, $S$. pecuarum Riley and $S$. meridionale Riley were supposed to carry cholera among chickens and hogs, but nothing definite was ascertained on this point.

${ }^{1}$ Georgewitch, Jiroin. Sur un Trypanosomide nouveau, Crithidia simuliae, n. sp. d'une Simulie (Simulium columbacensis) de la Serbie septentrionale. In Compt. Rend. Soc. Biol., t. 67, no. 31, p. 480-482, 1 fig., Nov. 12, 1909.

2 Op. cit., p. 510.

${ }^{3}$ See Bibliography, p. 35.

${ }^{4} \mathrm{Du}$ role des mouches dans la propagation du charbon et autres affections virulentes. In Jour. Med. Veter. Mil., t. 12, no. 8, p. 461-475, Paris, Jan., 1875. 
In 1905 Dr. Louis Sambon advanced the theory that pellagra might be transmitted by a blood-sucking fly of the genus Simulium. An accurate knowledge of the biology of the genus is very necessary in order to prove or disprove such a theory. It must be proved that Simulium not only bites in very large numbers, in order that a sufficient percentage of specimens will become infected which will live and become capable of transmitting pellagra, but it must also be proved that they will bite man after they have become infected, since hereditary transmission is probably entirely out of the question. Simulium exists in many places in large numbers, and if it should be proved that it normally requires a meal of the blood of vertebrates before it can fully develop the ovaries, then the chances that it may become infective are greatly increased.

Evidence on these points may be obtained in the following three ways:

(1) By rearing adult females from the immature stages, and then allowing them to engorge, oviposit, and reengorge. This method was tried a number of times, but with no success, for the fly will not readily engorge while in captivity, as was noted in the discussion of the feeding habits of the adult.

(2) By the capture of adults actually feeding on mammals, and by inducing them to oviposit and then to reengorge. This method also was unsuccessful for the same reasons.

(3) By dissections. If it could be proved that when a Simulium, which has once engorged on blood and oviposited, is still in a condition favorable to a second oviposition-that is, if rudimentary eggs are present in the ovaries awaiting only a second blood meal for their successful development-then there would be a more definite basis for a theory of disease transmission as opposed to the theory of merely a close coincidence in the distribution of pellagra and Simulium. This is the method adopted by the writer and is the one discussed in the following pages. The experiments were concluded in Spartanburg County, S. C., a country very favorable for the production of Simulium, being hilly and with a network of small streams, rapid and especially suitable for the development of the immature stages. The experiments on the actual biting and feeding habits were carried on more or less continuously from June 13 to September 16. The material for these experiments consisted of specimens of $S$. venustum; a good series of reared specimens (about 30); a number of females found engaged in oviposition; about 300 females all of which were taken in the act of engorging on mammals. Of the last named only about 90 were successfully dissected, as the engorged adults after death became internally disintegrated and hardened after an hour or so, despite every precaution. Many also died between midnight and $7 \mathrm{a}$. m., or while they were being transported from the place of 
capture to the laboratory. The adults, with the exception of 10 specimens killed at the time of capture, were kept alive as long as possible and dissected as soon as death was imminent. Some, in order that data might be obtained on their condition at the time of engorgement, were killed when captured and dissected within an hour.

\section{RECORDS OF DISSECTIONS.}

DEVELOPMENT OF THE OVARIES OF REARED NONFED ADULTS.

In order to have a check on the experiments with engorged adults, 32 females reared from isolated pupæ were kept alive as long as possible, without food, in bottles containing damp cloths. There were a number of males, reared from this same lot of pupæ, at liberty within the breeding cage together with these females, and copulation probably took place, but no definite statement can be made with regard to this point. Four females were killed and dissected within 6 hours after emergence. The remainder lived from a minimum period of $14 \frac{1}{2}$ hours to a maximum of 119 hours. All these specimens on dissection contained rather transparent ovaries of great potential development and full of round eggs (stage 1) (Pl. I, fig. 1, p. 4). In no instance did any one of these specimens develop the eggs within the ovaries as far as even the second stage. The maximum longevity of any nonfed reared specimen exceeded the maximum longevity of any specimen taken after engorgement by 52 hours. It would seem, therefore, that of these 32 reared specimens, there would have been 1 or 2 which would have dereloped the eggs within the ovaries, if it had been in the natural course of erents for them to do so.

\section{CONDITION OF THE OVARIES OF FEMALES FOUND OVIPOSITING.}

Eleven females were taken actually engaged in oriposition on grass blades in streams. When these specimens were dissected, there was found in each stomach a certain amount of substance closely resembling the digested blood found in engorged specimens which had lived after engorgement for 40 hours or more previous to their dissection. A chemical test for hæmatin was applied to the substance found in the stomachs of the females found ovipositing, in order to prove beyond doubt whether it contained animal blood or not, but, owing to the small quantity and the changes consequent to the process of digestion, it was impossible definitely to determine its character.

Three specimens were taken from grass blades in a stream on which they had just alighted and had not begun to oviposit. These specimens were at once dissected, and their ovaries were found to contain from 250 to 300 fully developed eggs. Four specimens were taken from egg masses deposited in the same situation, which had evidently 
just finished ovipositing. Four others which subsequently laid from 89 to 349 eggs while in captivity were also captured. The adults lived after oviposition from 15 minutes to $67 \frac{1}{2}$ hours, and were dissected immediately after death. Their ovaries were found to contain in each case a large quantity of eggs of the round type corresponding to stage 1 (Pl. I, fig. 1) with the exception of the specimen which lived only 15 minutes after oviposition and in which the eggs within the ovaries were only visible under a high magnification. The ovary of one specimen contained in addition, near the oviduct, a large fully developed egg which had not been deposited. This last-mentioned condition (stage 5, Pl. 1, fig. 5) was also found in adults taken engorging upon mammals and killed at the time of capture.

CONDITION OF THE OVARIES OF ADULTS TAKEN FEEDING ON MAMMALS.

In order to demonstrate the relation between the amount of engorgement and its apparent effect upon the development of the eggs within the ovaries, the condition of the ovaries is discussed collectively with regard to the previous amount of engorgement by adults, irrespective of the dates on which the adults were captured.

The following symbols are used in description to separate the varying degree: $(+)$ Slight and partial engorgement, or about onefourth the utmost capacity; $(++)$ fair engorgement, or one-half the utmost capacity; $(+++)$ well engorged, or three-fourths the utmost capacity; $(++++)$ complete engorgement, or distension of the abdomen to its utmost capacity.

CONDITION OF THE OVARIES OF ADULTS KILLED AT TIME OF CAPTURE.

Ten adults were taken from time to time engorging on the blood of mules. They were killed at once to obtain data on the condition of the ovaries at the time of engorgement. Two specimens were slightly engorged $(+)$; in one the ovaries showed a condition corresponding to stage 5, each ovary containing about 12 fully developed eggs, the remainder of the ovary being filled with eggs of the round type; in the other the ovaries contained only eggs of the round type in large quantity (stage 1). One specimen was half engorged $(++)$; its ovaries were in a condition typical of stage 5 , being filled with small round eggs and containing in addition 8 large fully developed eggs in a free condition, which seem positively to have been developed at a different period from the rest of the ovaries. One specimen was fairly engorged $(+++)$; the ovaries contained only eggs of the first stage in large numbers (stage 1). Six specimens were taken fully engorged $(++++)$; all of the ovaries were in a condition typical of stage 1 , the eggs being of the small round type, translucent, and in large numbers. 
In conclusion, there were only two stages found in the oraries of adults killed at the time of capture, either small, round, undereloped eggs in large quantity (stage 1), or round undereloped eggs with the addition of a rery fer large, fully dereloped eggs (stage 5). This latter stage is presumably the result of a prerious engorgement and oriposition.

CONDITION OF THE OVARIES OF NONENGORGED ADCLTS TAKEN ON ANIMALS.

Six specimens, which had evidently just alighted and had not fed on that particular animal, were taken at rarious times from mules' ears. They lired from 2 to 47 hours after capture, and the condition of the oraries in all these specimens was typical of stage 1 . There was no derelopment of the eggs within the oraries, and the condition seemed to be the same as in adults reared from pupæ and dissected shortly after emergence.

CONDITION OF THE OVARIES OF PARTLY ENGORGED ADULTS.

Twelve specimens were taken which had partly engorged $(+)$. The eggs within the oraries of fire of these specimens were not developed at all, and showed a condition corresponding to stage 1. These lived from 16 to 30 hours after capture. Three specimens showed the ovaries in a condition typical of stage 5, with from 1 to 4 fully developed eggs near the oriduct, and with the remainder of the ovaries filled with the small round type. These indiriduals lired from 12 to 21 hours after capture. The oraries of two specimens which lived for 52 and 53 hours, respectively, contained a large number of eggs between stages 2 (Pl. I, fig. 2) and 3 (Pl. I, fig. 3), almost oral in shape, about 200 in all. Two adults trere slightly more engorged than the rest, though not quite half engorged. They contained ovaries with eggs fully developed, of the same size and shape as eggs freshly deposited, but in rery small numbers as compared with those found in adults dissected before oriposition. There were about 30 eggs in the ovaries of one and 50 in the other, which lived 45 and 47 hours, respectively. These adults had possibly engorged once, oriposited, and then dereloped the remaining eggs in the oraries.

In the condition of the oraries of partly engorged adults these two points are worthy of notice: (1) No derelopment of the ovaries took place unless the longerity of a specimen exceeded 40 hours; (2) stage 5 recurred in three cases.

CONDITION OF THE OVARIES OF HALF-ENGORGED ADULTS.

Five half-engorged $(++)$ adults were taken. The oraries of two specimens contained eggs of the round type typical of stage 1 . They lived for 7 and 21 hours, respectively. One adult contained oraries filled with eggs of the typical oral shape (stage 3) in large 
numbers and dense white in color. This adult lived for 53 hours after engorgement. Two adults contained ovaries with fully developed eggs in small numbers. In one adult there were 25 eggs in each ovary and in the other 18 . Both these adults lived for only 4 hours and 35 minutes after capture. This is probably a case of second feeding, because adults which lived for so short a period after engorgement could not have developed fully formed eggs in that time. The explanation of this condition is that they had probably deposited only part of the full number of eggs at a previous oviposition.

CONDITION OF THE OVARIES OF WELL-ENGORGED ADULTS.

Twelve well-engorged ( +++$)$ adults were taken on various dates, these specimens lived after capture from 7 to 47 hours. Only one specimen contained ovaries corresponding to stage 1 . This specimen lived only seven hours and evidently had not had sufficient time in which to develop the ovaries. One specimen, which lived 17 hours, contained ovaries filled with eggs of stage 2, thus showing that the amount of development corresponds to the amount of engorgement and the requisite length of time after feeding. Six specimens, which lived from $17 \frac{1}{2}$ hours to 24 hours 45 minutes, contained ovaries filled with eggs of the oval type typical of stage 3, again showing a constant amount of development in proportion to the previous engorgement and subsequent longevity. One specimen, which lived for 43 hours, contained eggs of the oval type in a very small number, about 20 in each ovary, with the remainder of the ovary apparently filled with the eggs of the round type (stage 1). One adult contained ovaries with fully developed eggs, but only 27 in each ovary. This specimen lived for 30 hours. Two adults contained ovaries filled with fully developed eggs, over 100 in each ovary. These lived for 47 hours and evidently had the required factors, presumably a sufficient blood meal and sufficient time in which to digest, in order to develop the eggs within the ovaries.

The foregoing data seem to show again that the development of the eggs within the ovaries is increased by the amount of food plus the length of the period of digestion.

CONDITION OF THE OVARIES OF FULLY ENGORGED ADULTS.

Thirty-one fully engorged $(++++)$ adults were taken from time to time and successfully dissected. They lived from 30 minutes to $67 \frac{1}{2}$ hours. Six specimens contained ovaries corresponding to stage 1. These lived from 30 minutes to 4 hours 35 minutes. Two adults, which lived 17 and 24 hours, respectively, contained ovaries with the eggs between stages 2 and 3. Six specimens contained ovaries with eggs typical of stage 3 in large numbers. These lived from 18 to 
$28 \frac{1}{2}$ hours. One specimen which lired $23 \frac{1}{2}$ hours contained oraries with only a small number of eggs, about 25 in each orary. One adult which lired for 44 hours contained oraries betreen the third and fourth stages, and showed the transition from stage 3 to stage 4 rery clearly. Twelre adults contained oraries filled with fully dereloped eggs (stage 4, Pl. I, fig. 4), ranging in number from 200 to 300 . These adults liced from 30 to $67 \frac{1}{2}$ hours. Two adults contained oraries with eggs of stage 4 , but in small numbers, about 50 in each orary. They lired 48 and 56 hours, respectirely, and possibly had dereloped the remainder of the eggs left within the orary after a prerious oriposition. One adult contained oraries with eight fully dereloped eggs, and the remainder of the orary filled with eggs corresponding to stage 3 . This adult lired $3 t$ hours and had presumably oriposited once, as is indicated by the presence of the eight fully dereloped eggs, and then dereloped the remainder of the oraries to stage 3 .

A comparative study of the oraries of well-engorged $(+++)$ specimens shows that no adult which died before reaching a period of longerity of 30 hours after engorgement dereloped the eggs within the oraries to full degree. On the other hand, with one exception, all adults which lired for 30 hours after engorgement dereloped the eggs within the oraries to the fullest extent. The fully dereloped eggs within the oraries mere of the same shape as eggs freshly laid, and only a fraction smaller.

THE APPARENT EFFECT OF A BLOOD MEAL LPON THE DEIELOPMENT OF THE OFARIES.

In the studies which hare been made of the oraries of females of Simulium venustum under various conditions the following points are worthy of emphasis: (a) In all adults taken while oripositing, apparently digested blood was found in the stomach. (b) No eggs within the oraries dereloped to the fullest degree mithout engorgement and the requisite time in which to digest the blood meal. (c) The condition designated as stage 5 occurred both in adults which had just oriposited and also in adults which were taken on animals and killed at the time of capture. This condition (stage 5) seems to furnish strong evidence that adults feed again after oripositing, as the majority of engorged adults showed the entire contents of the oraries dereloped. In addition the exact cause of the similar condition found in adults which had just oriposited is known; namely, that a fer fully dereloped eggs $\pi$ ere left in the oraries after oriposition and the remainder of the eggs mere in a rudimentary condition apparently a maiting the necessare factors for derelopment. (d) The males hare reduced mouth parts and are not found engorging on blood, indicating the acquisition of this habit by the females for a special purpose, as is the case mith other blood-sucking Diptera. 


\section{BIBLIOGRAPHY. ${ }^{1}$}

*adams, C. F. Notes on and description of North American Diptera. Kan. Univ. Sci. Bul., v. 2, no. 14 (whole ser. v. 12, no. 14), p. 434, June, 1904.

Description of new species, Simulium notatum. Arizona.

*Agassiz, Louis. Lake Superior: Its Physical Character, Vegetation, and Animals, p. 34-35, 55, 61, 79, 115. Boston, 1850.

On species of Simulium, probably S. venustum, biting travellers in the North Woods.

*Aigner-Abafi, von L. Die Kolumbácser Fliege. In Allg. Ztschr., Ent., Bd. 8, no. 5, p. 93-96, 124-127, March, 1903.

Simulium in Austria.

*AldRich, J. M. A catalogue of North American Diptera. In Smithsn. Misc. Collect., v. 46, no. 1444, 680 p., 1905.

Pages 169-171. Simulium.

*Austen, Ernest Edward. Illustrations of British Blood-Sucking Flies (London, British Museum), p. 28-30, pl. 10, 1906.

Simulidæ, S. reptans Linn., notes and description, also colored floure.

*Austen, Ernest Edward. Illustrations of African Blood-Sucking Flies other than Mosquitoes and Tsetse-Flies. 221 p., 13 pl. London, July, 1909.

Pages 22-35, plate 1, figures 5-8. Simuliidæ. S. latipes Meig.; S. damnosum Theob.; S. wellmanni Roub.; S. griseicollis Becker; biology and references to habits in Africa.

*BAKER, C. F. Simulium ochraceum again. In Ent. News, v. 8, no. 7, p. 172, Sept., 1897.

Short note.

*Barnard, W. S. Notes on the development of a black-fly (Simulium) common in the rapids around Ithaca, N. Y. In Amer. Ent., v. 3 (n. S., v. 1), no. 8, p. 191-193, fig. 103, August, 1880.

Life history of Simulium pictipes Hagen.

*Becher, E. A new species of Simulium from Assam. In Jour. Asiatic Soc. Bengal, v. 53, pt. 2, no. 3, p. 199-200, 1884.

Description of Simulium indicum n. sp.

*Becker, A. Naturhistorische Mittheilungen. In Bul. Soc. Imp. Nat. Moscou, v. 37 , pt. 1 , p. $477-493,1864$.

Observations of two species of Simulium in the neighborhood of Sarepta.

*Becker, Th. Ägyptische Dipteren. In Mitteilungen Zoologischen Museum, Berlin, Bd. 2, Heft 3, p. 78-79. Berlin, 1903.

Simulidæ, description of new species S. griseicollis, Egypt.

*Becker, Th. Die Ergebnisse meiner dipterologischen Früjahrsreise nach Algier und Tunis f. 1906. In Zeitschrift Hymenopterologie und Dipterologie, Jahrg. 7, Heft 3, p. 241-242, May, 1907.

Simulidæ. List of species and including description of $S$. beckeri n. sp., by Roubaud.

*Becker, Th. Dipteren der Kanarischen Inseln. In Mitteilungen Zoologischen Museum, Berlin, Bd. 4, Heft 1, p. 1-180. Berlin, July, 1908.

Pages 72-74. Simulidæ. Descriptions of new species, S. annulipes, S. guimara. Canary Islands. 
*Bellardi, Luigi. Saggio di ditterologia Messicana. Pt. 1, p. 13-14. Torino, 1859.

Original descriptions of $S$. cinereum and $S$. metallicum.

*Bellardi, Lutgi. Saggio di ditterologia Messicana. Pt. 2 (Appendice, p. 6). Torino, 1862.

Simulidea. Original description of $\mathbb{S}$. mexicanum.

*Bigot, J. M. F. Diptères. In Mission Scientifique du Cap Horn, T. 6, p. 15-16. Paris, 1888.

Simulium from Cape Horn. Descriptions of S. anthracinum, S. antarcticum, new species.

*BIshopp, F. C. Some important insect enemies of lire stock in the United States. In U. S. Dept. Agr. Yearbook f. 1912, p. 383-396, fig. 11-14, pl. 38. The Buffalo gnat (S. pecuarum, fig. 11) and the turkey gnat (S. meridionale, fig. 12), after Riles, p. 383-386.

Bleyer, Henrik. A kolumbácsi légy. In Állatorrosi Lapok, v. 30, p. 291-292, June 15, $190 \pi$.

Simulium columbacsensis.

*Braun, Max. The Animal Parasites of Man. Ed. 3, London, 1906 . On S. maculatum, S. reptans, S. cinereum, S. damnosum.

*Bruxetti, E. New Oriental Nemocera. In Records of the Indian MIuseum, v. 4, no. 7, p. 259-316. Calcutta, 1911.

Pages 282-28S. Descriptions of new species: Simulium rufithorax, S. grisescens, S. metatarsalis, S. griseifrons, S. rufibasis, S. aureohirtum, S. senilis, India, Ceylon.

*Bruxetti, E. A new species of blood-sucking fly (Simulium) from Ceylon. In Spolia Zeylanica, v. 8, pt. 30, p. 90-91, 1 pl., June, 1912.

Simulium striatum n. sp. Ceylon.

*CAxtlie, James. Recent inrestigations on the etiology of pellagra. In Jour. Trop. Med., r. 15, no. 17, p. 262-265. London, 1912.

Mention of mosciolini (Simulium) as a possible agent in the transmission of pellagra.

*Carletti, M. V. Etiologia della Pellagra, L'ipotesi di L. W. Sambon. In Gazetta degli Ospedali delle Cliniche, Milan, r. 32, no. 64, p. 675-67т, May 28, 1911.

On Sambon's theory of the transmission of pellagra by insects, Simulium, Phlebotomus, etc.

*Carpenter, G. H. Insects: Their Structure and Life. 404 p., 183 fig. London, 1899.

Pages 124, 157; also fig. 160 (after Verdat), p. 293. Reference to the air bubble and its function in the ecdysis of Simulium pupæ. Short description of the genus.

*Cockerell, T. D. A. Notes from New Mexico. In Insect Life. T. T, no. 2, p. 211, Oct., 1894.

*Cockerell, T. D. A. A buffalo gnat new to the United States. Ent. News, v. 8, no. 5, p. 100, May, 1897.

Simulium ochraceum. Short note.

*Comstock, J. H. A Manual for the Study of Insects. 701 p., 797 fig., 1907.

Pages 451-453. Simuliidæ.

*Coquillett, D. W. The buffalo-gnats, or black-flies, of the United States.

U. S. Dept. Agr. Dir. Ent. Bul. 10, n. s., p. 66-69. 1898.

A synopsis of the family Simuliidæ. 
*Coquillett, D. W. New Diptera from Southern Africa. In Proc. U. S. Nat. Mus., v. 24, no. 1243, p. 27-32, 1902.

Page 27. Description of Simulium nigritarsis, South Africa, n. sp.

*Cotes, E. C. Indian Museum Notes, v. 3, p. 39-41, Calcutta, 1894.

On the Potu fly, Simulium indicum.

*Crumbine, S. J. Pellagra in Kansas. Kansas State Board of Health Bul., v. 7 , no. 10 , p. 190 , Oct., 1911.

Mention of distribution of Simulium in Kansas.

*CuRtis, JoHn. British Entomology, v. 16, pl. 722-769, London, 1839.

Plate 765. Simulium trifasciatum. Description of the structural characters of the genus and designation of Culex sericea Linné as type of the genus Simulium.

*Damann und Oppermann. Simulia Ornata als Vremittler der Wild und Rinderseuche. In Deut. Tierarztl. Wchnschr., v. 13, no. 44, p. 505-506, Nov. 4, 1905.

*DoAne, R. W. Insects and Disease, 227 p., 112 fig. New York, 1910.

Page 46, fig. 24 (after Kellogg).

Doran, E. W. The buffalo gnat. Report on the Economic Entomology of Tennessee. In Biennial Rpt. Commr. of Agr., etc., of Tennessee, p. 239-242.

Еіснновл, J. C., Beitrage zur Naturgeschichte der kleinsten Wasserthiere, die mit keinem blossen Auge gesehen werden können. 94 p., 8 tab., Danzig, Müller, 1776.

*Emery, W. T. The Morphology and Biology of Simulium vittatum and its Distribution in Kansas. Kansas Univ. Sci. Bul., v. 8, no. 9 (Whole Ser., v. 18, no. 9), p. 323-362, pl. 38-42, March, 1914.

*[Ent. Nachr. Jahrg. 10, no. 15, p. 234-235, Aug., 1884.]

*Fabricius, Отто. Fauna Groenlandica. p. 210, Hafniæ et Lipsiæ, 1780.

Culeo reptans Linn. $=$ Simulium reptans.

*Fabricius, Otтo. Beschriebung der Atlasmucke und ihrer Puppe (Tipula Serica). In Schriften der Berlinischen Gesellschaft Naturforschender Freunde, v. 5, p. 251-259, pl. 3, 1784.

Plate shows a figure of the pupa, cocoon, and imago.

*Fabricius, Joh. Christ. Entomologia Systematica, t. 4, p. 276, 1794. Rhagio colombaschensis Fab. Original description.

Filipp, Eduard. Die Gollubatzer Mucke (Simulia columbaczensis). In Termés zettud. évkönyv. Temesvár. II. Évfoly, p. 95-103, 1875-1876.

Föld, János. Természeti História, p. 355, 1801.

*Forbes, S. A. On black-flies and buffalo-gnats (Simulium) as possible carriers of pellagra in Illinois. In 27th Rpt. State Ent. Ill. f. 1912, p. 21-55, fig. 1-25.

Descriptions of S. johannseni Hart. and S. venustoides Hart n. sp.

*FrIES, B. F. Observationes entomologicæ, Pt. I. Monographia Simuliarum sveciæ, Lundæ, 1824.

*Garman, H. Silk spinning fly larvæ. In Science, v. 22, no. 559, p. 215-217, 4 fig., Dec., 1893.

* Garman, H. A preliminary study of Kentucky localities in which pellagra is prevalent. Kentucky Agr. Expt. Sta. Bul. 159, 79 p., 65 fig., Jan., 1912.

On the life history and early stages of Simulium venustum with several very good figures of structural characters. 
*Georgévitch, Jivoïn. Sur un Trypanosomide nouveau, Crithidea simulia, n. sp. d'une Simulie (Simulium columbacensis) de la Serbie septentrionale. In Compt. Rend. Soc. Biol., t. 67, no. 31, p. 480-482, Paris, 1909.

An organism found in the digestive tract of blood-sucking female Simulium.

*Georgévitch, JivoÏN. Note relative a la Biologie et au système digestif de Simulium columbacensis. In Compt. Rend. Soc. Biol., t. 67, no. 33, p. 540542, Paris, 1909.

*Goeldi, Emilio Augusto. Os Mosquitos no Pará. In Memorias do Museu Gœldi, v. 4, p. 138-139, Pará (Brazil), 1905.

On the "pium"; original description of simulium amazonicum.

*Gordon-Hewrtt, C. Simulium flies and pellagra. In Nature, v. 85, p. 169-170, 1910.

Short note.

*Graber, V. Simulia, Chironomus. In Denkschriften der kaiserlichen Akademie der Wissenschaften, Bd. 55, p. 142-144, pl. 8, fig. 48-54, Wien, 1889.

*Grünberg, K. Diptera, Zweiflügler. In Die Süsswasserfauna Deutschlands, Heft 2A, 312 p., 3.48 fig. Jena, 1910.

Pages 106-112, figures 126-130. List of most of the European species of Simulium to date, with descriptions of the adults, larvæ, and pupæ.

*HAgen, .H. A. A new species of Simulium with a remarkable nympha case. In Proc. Boston Soc. Nat. Hist., v. 20, p. 305-307, Oct., 1879.

*Hagen, H. A. On Simulium. In Canad. Ent., v. 13, No. 7, p. 150-151, July, 1881.

*Hagen, H. A. Simulium feeding upon chrysalids. In Ent. Mo. Mag., v. 19, p. 254-255, April, 1883.

Simulium attacking and feeding on the chrysalids of Pieris menapia.

Handlinsch, Anton. Die Fossilen Insekten, p. 631, 981-982, 1186, 1192, 1259, 1262, 1270, 1287, 1292. Leipzig, 1908.

Familie: Simulidae. Fossil species in amber.

*Harris, T. W. Treatise on Some of the Insects Injurious to Vegetation. New ed., 640 p., 278 fig., Boston, 1862.

Pages 601-602. Simulium molestum and S. novicum.

*Heeger, E. Beiträge zur Naturgeschichte der Kierfe. In Isis von Oken, vi 41, no. 5, p. 319-348, pl. 4. 1848.

Page 328. Simulium colombaschense.

*Hendel, Friedrich. Nouvelle classification des mouches á deux ailes (Diptera L.). In Verhandl. k. k. zool. bot. Gesell. Wien, Bd. 58, p. 43-69. 1908.

Page 50. Melusina revived and Simulium Latr. put in synonymy.

Herman, Otтo. A Kolumbácsi legyröl. In Természettudományi Kózlony, v. 8, no. 82, p. 236-239, 6 fig., June, 1876.

*Herrick, G. W. Some insects injurious to stock and remedies therefor. Mississippi Agr. Expt. Sta. Bul. 53, 8 p., March, 1899.

Pages 2-4. The Southern buffalo gnat. (Simulium pecuarum Riley.)

HeUfFel, JÁxos. A kolumbáczi tipolya. In A Magyar Természettudományi Társulat Evkönyvel, v. 2, p. 44-59, 1845-1850.

*Hewitt, C. Gordon. See Gordon-Hewitt, C.

*Holmgren, A. E. Insekter fran Nordgrönland. In Öfvers. K. Svenska Vetensk. Akad. Förhandl., v. 29, no. 6, p. 97-105, 1872.

Page 104. Fam. Simulides, Simulia vittata. Short reference. 
*Horvath, Geza. A kolumb̉ácsi légy. In Rov. Lapok., v. 1, no. 10, p. 195-204, pl. 3, 10 fig., Oct., 1884.

Biology of Simulium colombaschensis=Simulium reptans.

*[Howard, L. O. Larva of Hydropsyche feeding on larvæ of Simulium.] In U. S. Dept. Agr. Ann. Rpt. Fnt. f. 1886, p. 510, 1887.

*Howard, L. O. Notes on Simulium common at Ithaca, N. Y. In Insect Life, v. 1 , no. 4 , p. 99-101, Oct., 1888.

*Howard, L. O. Death web of young trout. In Insect Life, v. 7, no. 1, p. 50, Sept., 1894.

Note on a Simulium in relation to fish.

*Howard, L. O. The buffalo gnat. In Insect Life, v. 7, no. 5, p. 426, July, 1895. Note on occurrence in Louisiana.

*Howard, L. O. Simulium and pellagra. In U. S. Dept. Agr. Ann. Rpt. Ent. f. 1911, p. 34 .

*Hungerford, H. B. Anatomy of Simulium vittatum. In Kansas Univ. Sci. Bul., v. \&, no. 10 (whole ser., v. 18, no. 10), p. 365-382, pl. 43-45, 1914.

*Hunter, S. J. The sand-fly and pellagra. In Jour. Econ. Ent., v. 5, p. 61-64, 1912.

*Hunter, S. J. University experiments with sand fly and pellagra. Kansas Univ. Sci. Bul., v. 8, no. \& (whole ser., v. 18, no. 8), p. 313-320, 1914.

*Jennings, Allan H., and King, W. V. One of the possible factors in the causation of pellagra. In Jour. Amer. Med. Assoc., v. 60, p. 271-274, Jan., 1913.

Reference to Simulium and statement questioning the probability of the Simulium theory of pellagra.

*Jennings, Allan H., and King, W. V. An intensive study of insects as a possible etiological factor in pellagra. In First Progress Rpt. of the Thompson-McFadden Pellagra Commission, p. 81-110, March, 1914.

Pages 93-100. Simuliidæ. Simulium pictipes, S. venustum, S. vittatum.

*Joan, Terisa. Nota sobre un Diptero ponzoñosa. In Boletin del Ministerio de Agricultura, t. 14, no. 4, p. 363-385, 11 fig., 1 pl. Buenos Aires, April, 1912.

Description of Melusina dinellii=Simulium dinellii new species from Alparhiri. Tucuman, Argentina; also biological data, and colored and text figures;

*Johannsen, O. A. Notes on some Adirondack Diptera collected by Messrs. MacGillivray and Houghton. In Ent. News, v. 14, no. 1, p. 14-17, Jan., 1903.

*Johannsen, O. A. Aquatic Nematocerous Diptera. In N. Y. State Mus. Bul. 68 , pt. 6, p. 328-441, pl. 32-38, 1903.

Simuliidæ: Biology and list of the North American species, with keys and descriptions, also many excellent illustrations of the structural characters of the immature stages.

*Johannsen, O. A. Insect notes for 1910. Maine Agr. Expt. Sta. Bul. 187, 24 p., 37 fig., 1911.

Pages 4-5. Simulium and pellagra.

*Kellogg, Vernon L. Food of larvie of Simulium and Blepharocera. In Psyche, v. 9, no. 298, p. 166-167, Feb., 1901.

*King, Harold H. Biting and noxious insects other than mosquitnes. In Second Rpt. Wellcome Research Laboratories, Gordon Memorial College, Khartoum, p. 29-50, pl. 1-3, fig. 12-20, 1906.

Biological and other notes on "Kunteb" and "Nimitta," Simulium damnosum and S. griseicollis. 
*KING, HaRoLd H. Report on economic entomology. In Third Rpt. Wellcome Research Laboratories, Gordon Memorial College, Khartoum, p. 201-248. 1908.

Pages 206-209. Sandflies, "Nimitti" (Simulium griseicollis Becker) and "Kilteb" (S. damnosum Theob.).

*Kirby and Spence. Introduction to Entomology. Ed. 4, v. 1, p. 151-153. London, 1822.

Simulium attacking man and animals. Reference to Rhagio cohumbaschensis.

*KNAB, F. Dr. A. Lutz's studies of Brazilian Simuliidæ. In Proc. Ent. Soc. Wash., v. 13, p. 172-179, 1911.

* KNab, F. A note on some American Simuliidæ. In Insecutor Inscitiæ Menstruus, v. 1, no. 12, p. 154-156, Dec., 1913.

*KNAB, F. Simuliidæ of Peru. In Proc. Biol. Soc. Wash., p. 81-86, May 11, 1914.

Description of new species. Simulium gaudeatum, S. flavipictum, S. spinifer, S. seriatum, S. chalcocoma.

*Kollar, Vincent. A Treatise on Insects Injurious to Gardeners, Foresters and Farmers. (Translation from German by J. and M. Loudon), 377 p., figures. London, 1840.

Pages 68-73. On the attacks of Simulium columbaschense in Servia upon man and animals.

*Kollar. Beurtheilung des von Dr. Medovics an die serbische Regierung erstatteten Berichtes über Enstehung und Vertilgung der Gollubatzer Mucken. In Sitzber. K. Akad. Wiss. [Vienna], Math. Naturw. Kl., Bd. 1, p. $92-107$, pl. 1-3, 1848.

On Simulium sericeum Meig.

* Kölliker, Alberto. Observationes de prima insectorum genesi. In Ann. Sci. Nat. Zool., ser. 2, t. 20, p. 253-283, pl. 11. Paris, 1843.

Pages 265-266. Simulia canescens, embryology.

*Latreille, P. A. Histoire Naturelle, v. 14, 432 p. Paris, 1805.

Page 294. The 477th Genre Simulie: Simulium. Original description of the genus.

*Lavinder, C. H. The theory of the parasitic origin of pellagra. In Public Health Reports, v. 25, no. 21, p. 235-237. Washington, June, 1910.

Summary of the "Simulium theory." (Simulium reptans.)

*Lavinder, C. H. A report of the second triennial meeting held at Columbia, S. C., Oct. 3-4, 1912. In Public Health Reports, v. 27, no. 44, p. 1776-1778, Nov., 1912.

*Lefroy, H. Maxwell. Indian Insect Life, 786 p., 83 pl., 536 fig. Calcutta and Simla, 1909.

Pages 587-588, pl. 61. Simulium in India. Observations on Simulium indicum Becher and S. indianum Big.

*Leon, N. Le Simulium columbaczense de Roumanie. In Centbl. Bakt., Abt. 1, v. 51, p. 659-668, 11 fig. Jena, 1909.

A careful study of the structure of the mouth parts of Simulium.

*Leтнӧ, Julrus. Hungarian Earthquakes and the Kolumbács flies. In Nature, v. 21, p. 202, Jan., 1880.

*Liebe, Johannes. Die larva von Simulia ornata Mg. (with 16 figs. in the text). In Zeitschrift fur Naturwissenschaften, Bd. 82, Heft 3-5, p. 345-372. Leipzig, 1910.

*Linnaus, Carolus. Lachesis Lapponica. Translated by J. E. Smith, v. 1, 366 p. London, 1811.

Pages 208-209. On attacks of Culex reptans in Pithoea. 
*Linnaus, Carolus. Flora Lapponica, 390 p., 12 pl. London, 1792.

Pages 382-383. Description of Culex pulicaris $=C$. reptans $=$ Simulium reptans. Known locally as "knort."

*Loew, H. Diptera Americæ septentrionalis indigena. Centuria secunda. In Berlin. Ent. Ztschr., v. 6, p. 185-232. Berlin, 1862.

Page 186. Simulium quadrivittatum, description of new species.

*Lounsbury, Charles P. Insect pests in South Africa. In Science in South Africa, p. 362-374, 1905.

Simulium attacking poultry (brief mention), South Africa.

*Lugger, Otto. Insects injurious in 1896. Univ. Minn. Agr. Expt. Sta. Ent. Div. Bul. 48, 270 p., 16 pl., 187 fig., 1896.

Pages 198-208. Description of new species: Simulium minutum; S. irritatum; S. tribulatum $=$ S. vittatum.

*LundBeck, WrLL. Diptera Groenlandica. In Videnskabelige Meddelelser fra den naturhistoriske Forening i Kjobenharn, p. 281-316, 5 fig., 1900.

*Lundström, CarL. Släktet Simulium Latr. In Meddelanden af Societas pro Fauna et Flora Fennica, Heft 36, p. 103-104, 1910.

*Lundström, Carl. Beiträge zur Kenntnis der Dipteren Finlands, VII. Molusinidæ (Simuliidæ). In Acta Soc. pro Fauna et Flora Fennica, v. 34, no. 12, 24 p., 26 fig., Dec., 1911.

A study of the male genitalia, showing the systematic value of the structures.

*Lutz, A. Memorias do Instituto Oswaldo Cruz, t. 1, p. 124-146. Rio de Janeiro, 1909.

Page 132, description of Simulium rubrithorax; p. 133, S. scutistriatum; p. 135, S. hirticosta; p. 141, S. exiguum and S. varians; p. 137, spp. n. Brazil. S. venustum var, infuscata.

*Lutz, A. Memorias do Instituto Oswaldo Cruz, t. 2, p. 213-267, 1910.

Descriptions: S. infuscatum, p. 236; S. orbitale=nigrimanum Macq., p. 231; S. auristriatum, p. 245 ; S. incrustatum, p. 243 ; S. distinctum, p. 241 ; S. subnigrum, p. 239 ; S. subpallidum, p. 247 ; S. flavopubescens, p. 248; S. pruinosum, p. 250 ; S. simplicicolor, p. 251 ; S. minusculum, p. 253 ; S. rotulibranchium, p. 256 ; S. clavibranchium, p. 257 ; S. diversifurcatum, p. 258 ; S. arquifurcatum, S. brevibranchium, p. 260 , spp. n. Brazil.

*McBride, Sara J. The so-called web-worm of young trout. In Amer. Ent. and Bot., v. 2, no. 12, p. 365-366, Dec., 1870.

*Macquart, M. Histoire Naturelle des Insectes, Diptères. v. 1, p. 173-175, pl. 4, fig. 15. Paris, 1834.

Simulie. Simulium Latr. Description of genus and list of species. One colored figure of $S$. ornatum.

*Malloch, J. R. One new genus of dipterous insects in the U. S. National Museum collection. In Proc. U. S. Nat Mus., v. 43, no. 1945, p. 649-658, pl. 46, 1913.

Page 649 , pl. 46 , fig. 67 , Simulium bicoloratum; p. 650, fig. 8 , S. bipunctatum; p. 650 , fig. 9 , S. townsendi; p. 652, S. nitidum. Locality, Peru.

*Malloch, J. R. American black flies or buffalo gnats. U. S. Dept. Agr. Bur. Ent. Tech. Ser. no. 26, 71 p., 6 pl., 1914.

Descriptions of new species: Prosimulium pleurale; Prosimulium mutatum; Parasimulium new genus; Parasimulium furcatum; Simulium aureopunctatum; S. hippovorum; S. trivittatum; S. bivittatum; S. parnassum; S. arcticum; S. jenningsi; S. clavipes; S. hunteri; S. hæmatcpotum; S. forbesi.

*Marlatt, C. L. Report of a trip to investigate buffalo gnats. In Insect Life, v. 2 , no. 1 , p. 7-11, July, 1889. 
*Marshall, P. New Zealand Diptera. In Trans. and Proc. N. Zeal. Inst., v. 28, art. 26, no. 3 (Simulidæ), p. 310-311, pl. 14, June, 1896.

Simulium austratiense in New Zealand.

*Mecznmow, Elias. Embryologische Studien an Insecten. In Ztschr. Wiss. Zool., Bd. 16, Heft 4, p. 3S9-500, pl. 23, fig. 1-24. Leipzig, Dec. 6, 1866.

A detailed study of the embryology of several insects. Aphis rosa, Chironomus etc., including detailed account of the embryology of Simulium with excellent illustrations.

*Megnin, J. P. Du rôle des mouches dans la propagation du charbon et autres affections virulentes. In Jour. Med. Veter. Mil., t. 12, no. 8, p. 461-475. Paris, Jan., 1875.

Simulium maculatum and S. cinereum transmitting diseases of cattle.

*Megnin, J. P. Les Parasites et Les Maladies Parasitaires chez l'Homme, les Animaux Domestiques et les Animaux Saurages arec Lesquels ils Peuvent etre en Contact; Insectes, Arachnides, Crustacés. 478 p., 26 pl., 63 fig. Paris, 1880.

Pages 47-51. Mouches piquantes, Simulium, causing a psoriasis in the ears of horses, and also transmitting charbon.

*Meigen, J. W. Versuch einer neuen Gattungs-Lintheilung der europäischen zweiflügligen Insekten. In Magazin für Insektenkunde herausgegeben von Karl Illiger, v. 2, p. 259-281. Braunschweig, 1803.

*Meigen, J. W. Klassification und Beschreibung der europäischen zweiflüglichen Insecten, t. 1. Braunschweig, 1804.

*Meijere, J. C. H. DE. Studien über Südostasiatische Dipteren. In Tijdschr. Ent., v. 50, p. 196-264, pl. 5-6. 's-Grarenhage, Dec. 31, 1907.

Pages 206-207. Description of Simulium nobile, male, new species from Java.

*Meijere, J. C. H. DE. Blutsaugende Micro-Dipteren aus Niederländisch Ostindien. In Tijdschr. Ent., v. 52, pl. 12, p. 191-204. 's-Gravenhage, Dec., 1909. Pages 202-203. Simulium nobile, female. Description.

*Meinert, Fr. De eucephale Myggelarver. In K. Danske Vidensk. Selsk. Skr., ser. 6, v. 3, art. 4, p. 373-489, pl. 4, fig. 11.5-127, 1886.

Pages 458-464. Anatomy of Simulium ornatum, with bibliography.

*Meinert, Fr. Fluernes Munddele Tropi Dipterorum, 91 p., 6 pl. Kjobenhavn, 1881.

Pages 41-43. Simulium fuscipes; S. reptans; mouth parts of adults.

*Meunier, Fernand. Beitrag zur Fauna der Bibioniden, Simuliden, und Rhyphiden des Bernsteins. In Jahrb. Königlich Preuss. Geol. Landesanstalt und Bergakarlemie, Bd. 24, p. 391-404, pl. 17, fig. 8-11. Berlin, 1903.

Pages 397-398. Descriptions of new fossil species, Simulium pulchella, S. affinis, S. importuna.

*Mrade, L. C. The Natural History of Aquatic Insects. 395 p., 116 fig. London, 1895.

Pages 175-188. Simulium.

* Moore, H. W. B. Blood-sucking flies other than mosquitoes. In Jour. Roy. Agr. and Com. Soc. British Guiana, v. 1, ser. 3, p. 255-259, 1911.

Simulium in British Guiana. Note on distribution.

Mocsárx, SÁndor. A kolumbácsi légy. In Vasárnapi Ujság, évfoly, 21 szam., p. 329-330. 1876.

Die Fliege von Kolumbacz.

*MüLler, Fritz. Larven von Mücken und Haarflüglern mit zweierlei abwechselnd thätigen Athemwerkzeugen. In Ent. Nachr., v. 14, no. 18, p. 273-277, Sept., 1888. 
*Newstead, Robert. Insects and other Arthropoda collected in the Congo Free State. In Ann. Trop. Med. Par., v. 1, no. 1, p. 3-112, pl. 1-6, Feb. 1, 1907. Mention of Simulium damnosum; S. ornatum, habits and structural characters (European species).

*Needham, J. C., and Betten, C. Aquatic insects in the Adirondacks. N. Y. State Mus. Bul. 47, p. 383-612, 36 pl., 42 fig., 1901.

*Nicéville, Ltonel de. Note on the "Potu" or "Pipsa" fly. In Indian Mus. Notes, v. 4, no. 2, p. 54-55. Calcutta, 1896.

*Nicholls, Lucius. Pellagra. "Sandfly Protozoon" versus "Zeist" theory. In Jour. Trop. Med., v. 15, no. 20, p. 305-306. London, 1912.

*Noel, Paul. La Mouche de Goluobatss. In Le Naturaliste, ser. 2, année 2S, no. 452, p. 13. Paris, Jan. 1, 1906.

*Osborn, Herbert. An old American account of the buffalo gnat. In Insect Life, v. 1, no. 7, p. 224-225, Jan., 1889.

*Osborn, Herbert. Insects affecting domestic animals. U. S. Dept. Agr., Liv. Ent., Bul. 5, n. s., 302 p., 5 pl., 170 fig., 1896.

Pages 31-58. Simuliidæ.

*Osten-Sacken, R. On the transformations of Simulium. In Amer. Ent., v. 2, no. 8, p. 229-231, fig. 145-147, June, 1870.

*Packard, A. S. History of the buffalo gnat. In Amer. Nat., v. 20, no. 7, p. $650-651,1886$.

Habits of Simulium larvæ in North America.

*Packard, A. S. Our Common Insects. 225 p., 268 fig. Salem, 1873.

Pages 72-73. The black fly.

*Philippi, R. A. Aufzählung der chilenischen Dipteren. In Verhandl. k. k. zool. bot. Gesell. Wien, Bd. 15, p. 595-782, 1865.

Pages 633-635. Simulium fulvescens Blanch. Descriptions of new series, S. montanum, S. pulchrum, S. annulatum, S. varipes, S. chilense, S. tarsatum. Chile.

*Planchon, J. E. Histoire d'une Larve Aquatique du Genre Simulium. 15 p. Montpellier, 1844.

Poнц, J. E. Reise in das Innere von Brasilien. 2 volumes. Wien, 1832.

*Pryer, H. Simulium attacking larvæ in Japan. In Ent. Mo. Mag., v. 24, p. 156-157. London, 1887.

* Reeves, Cora D. A remedy for the black Hy pest in certain streams of the Southern Peninsula of Michigan. In 12th Rpt. Mich. Acad. Sci., p. 77-78, 1910.

* Riley, C. V. The death-web of young trout. In Amer. Ent. Bot., v. 2, no. 8, p. 227-228, fig. 143-144, June, 1870.

*RIr.ey, C. V. Simulium piscicidium, n. sp. In Amer. Ent. Bot., v. 2, no. 12, p 367, December, 1870.

Appendix to Sara J. McBride's article.

*RIley, C. V. On Simulium pictipes Hagen. In Amer. Nat.. v. 15, no. 4, p. $330,1881$.

*RILey, C. V. Simulium from Lake Superior. In Amer. Nat., v. 15, no. 11, p. 916, 1881.

*RItex, C. V. The southern buffalo gnat (Simulium sp.). In Rpt. U. S. Comr. Agr. f. 1884, p. 340-345, pl. 9, fig. 1-3, 1884.

Simulium ravages, etc. 
*RIIEr, C. V. Report of the Entomologist. In Rpt. U. S. Comr. Agr. f. 1886, p. 459-592, $11 \mathrm{pl}$.

Pages 461,492 , 517. The southern buffalo gnat, simulium pecuarum, and the turkey gnat, S. meridionale n. sp.

*Ruer, C. V. A Tirginia Simulium, called the "cholera gnat," also reply to letter suggesting remedy. In Insect Life, r. 1, no. 1, p. 14-15, July, 1888.

*Riler, C. V. Buffalo gnats attacking man. In Insect Life, v. 1, no. 2, p. 60-61, Aug., 1888.

*Riley, C. Y., and Howard, L. O. Formula for a buffalo gnat application. Letter by Miss P. H. Skipwith. In Insect Life, v. 1, no. 5, p. 143, Nor., 1888.

*RILEs, C. V. Buffalo gnats on the Red Rirer. (Letter by G. A. Frierson and reply.) In Insect Life, v. 1, no. 10, p. 313-314, April, 1889.

*RILer, C. T., and Howard, I. O. A phase of buffalo gnat injury. In Insect Life, v. 2, no. 1, p. 2, July, 1 s\$9.

Short note.

*RILey, C. V., and Howard, L. O. Notes on buffalo gnats. (Letter by G. A. Frierson and reply.) In Insect Life, r. 4, nos. 3 and 4, p. 143-144, Nor., 1891.

*Riler, C. T., and Howard, L. O. Great damage by buffalo gnats. In Insect Life, v. 4, p. 406, Aug., 1892.

*Riner, C. V., and Howard, L. O. A new Simulium. In Insect Life, r. 5, p. 61, Sept., 1892.

Note on Simulium occidentale Townsend.

*RIler, C. V., and Howard, L. O. In Insect Life, r. 5, p. 81, Nor., 1892. Reference to Simulium occidentale and irrigation.

*Roberts, S. R. Sambon's new theory of pellagra and its application to conditions in Georgia. In Jour. Amer. Med. Assoc., v. 56, no. 23, p. 1713-1715, June, 1911.

*Roberts, S. R. The analogies of pellagra and the mosquito. In Amer. Jour. Med. Sci., r. 146, no. 2 (no. 497), p. 233-23S, Aug., 1913.

*Roubaud, E. Les Mouka-Fouhi, Simulies nourelles de Madagascar. In Bul. Mus. Hist. Nat., v. 11, no. 6, p. 424-427. Paris, 1905.

*Roubaud, E. Simulies du Nippon Moyen. In Bul. Mus. Hist. Nat., r. 12, no. 1, p. 24-27, fig. 1-2. Paris, 1906.

*RoubaUd, E. Apercus noureaux, morphologiques et biologiques, sur les Diptères piqueurs du groupe des Simulies. In Compt. Rend. Acad. Sci., t. 143, p. 519-521. Paris, Oct. 8, 1906.

*Roubaud, E. Sur deux ț̣pes intérressants de simuliides de l'Afrique équatoriale et des Nouvelles-Hébrides. In Bul. Mus. Hist. Nat., v. 12, no. 3, p. 140-143, 1 fig. Paris, 1906.

*Roubaud, E. Insectes Diptêres. Simulies nourelles ou peu connues. In Bul. Mus. Hist. Nat., v. 12, no. 7, p. 517-522. Paris, 1906.

*Roubaud, E. Simulies nourelles de l'Amerique du Sud. In Bul. Mus. Hist. Nat., г. 12, no. 2, p. 106-110. Paris, 1906.

*Roubaud, E. Description of Simulium beckeri n. sp. In Ztschr. Hrmenopterologie und Dipterologie, v. 7, no. 3, p. 241-242, Jan. 1, 1907.

*Roubaud, E. Note biologique sur un type adapté de Simulium reptans du Congo équatorial. In Ann. Inst. Pasteur, v. 21, p. 670-671. Paris, 1907.

*Roubaud, E. Description d'une Simulie nourelle du Pérou. In Bul. Soc. Pathologie Exotique, t. 2, no. 7, p. 428-430. Paris, 1909.

Description of a new species, Simulium escomeli, Peru. Also a definition of the subgenera Prosimulium and Eusimulium. 
*Rudow. Schädliche Mücken in der Mark. In Ent. Nachr., v. 4, no. 16, p. 213-214.

Describes the attacks of Simulium maculata and S. reptans upon horses and cattle throughout the valley of the Elbe.

*Rudow. Die Kolumbaczer-Mücke. In Insektenbörse, v. 20, no. 35, Aug., 1903.

*Sambon, L. W. Progress report on the investigation of pellagra. In Jour. Trop. Med., v. 13, no. 18, p. 271-282 and no. 19, p. 287-300, Sept. and Oct., 1910.

That a minute blood-sucking fly of the genus Simulium is in all probability the agent by which pellagra is conveyed.

*Sanderson, E. D. Controlling the black fly in the White Mountains. In Jour. Econ. Ent., v. 3, no. 1, p. 27-29, pl. 2-3, Feb., 1910.

*Say, Thomas. Entomology of North America, v. 2, p. 51, 1823. (Also in Jour. Acad. Nat. Sci. Philadelphia, v. 3, p. 28, 1823.)

*Schiner, J. R. Fauna Austriaca, v. 2, p. 363-369. Wien, 1864.

Family Simulidæ. Simulia=Simulium Latr. Description of genus and list of species.

*Schiner, J. R. Reise der öerterreichischen Fregatte Novara um die Erde. In Zoologischer Theil., Bd. 2, 385 p., 4 pl., 1868.

Page 15. Simulium ornata and description of S. australensis n. sp.; also mentions number of described species to date.

*Schiöpte, J. G. Uebersicht der Land-Süsswasser-und Ufer-Anthropoden Grönlands. In Berlin. Ent. Ztschr., v. 1, p. 152. Berlin, 1859.

Antliata—Simulia vittata Zett. 1859.

Sсніӧрте, J. G. S. fuscipes. Kvaegmyggen. In Berlingske Tidende. May 16, 1878.

Schönbauer, J. A. Geschichte der Schädlichen Kolumbatczer Mücken im Bannat, als ein Beytrag zur Naturgeschichte von Ungarn. 100 p., 1 pl., Wien, 1795.

*Schrottky, C. Drei neue blutsaugende Dipteren aus Paraguay. In Ztschr. Wiss. Insektenbiologie, Bd. 5, pt. 2, p. 61-63, 1909.

Descriptions of new species: S. inexorabile, S. paranense, S. paraguayense, Paraguay.

*Shelford, R. Simulium and pellagra. In Nature, v. 85, no. 2141, p. 41. London, 1910.

*Skuse, F. A. A. Diptera of Australia, Simulidæ and Bibionidæ. In Proc. Linn.

Soc. N. S. Wales, ser. 2, v. 3, pt. 4, p. 1363-1386, pl. 39, 1888.

Page 1365, fig. 1. Description of S. furiosum. Figure of wing.

*Skuse, F. A. A. Diptera of Australia. In Proc. Linn. Soc. N. S. Wales, ser. 2, v. 5, p. 595-640, pl. 19, 1890.

Page 632. Simulium ornatipes, new species, Australla.

*Sмiтh, J. B. A contribution toward a knowledge of the mouth parts of the Diptera. In Trans. Amer. Ent. Soc., v. 17, p. 319-339, 1890.

Pages 323-326, fig. 4. Mouth parts of the buffalo gnat described and figured.

*Speiser, P. Zur Nomenclatur blutsaugender Dipteren Amerikas. In Insektenbörse, 21 Jahrg., nr. 18, p. 148, May 5, 1904.

*StAgGer, C. Groenlands Antliater. In Naturhistorisk Tidsskrift, 2 R., 1 Bind, p. 346-370. Kфbenhaven, 1844-1845.

Page 357. Simulia vittata. 
*Strickland, E. H. Some parasites of Simulium Jarvæ and their possible economic value. In Canad. Ent., v. 45, no. 12, p. 405-413, pl. 15, 1913.

*Strickland, E. H. Some parasites of Simulium larvæ and their effects on the development of the host. In Biol. Bul., v. 21, no. 5, p. 302-338, 5 pl. Boston, 1911.

*Strobl, Gabriel P. Dipterenfauna von Bosnien, Hercigovina und Dalmatia. In Wissenschaftliche Mittheilungen, Bosnien und der Hercegovina, Bd. 7, p. 552-670. Wien, 1900.

Pages 648-649. Simulidæ, description of S.argenteostriata $\mathrm{n}$. sp. and S. ornata Meig. var flaviventris.

*Summers, S. L. M. Description of a new species of Simulium from the Siamese Hills, S. nigrogilvum. In Ann. and Mag. Nat. Hist., ser. 8, v. 7, no. 42, p. 5S6-5S8. London, 1911.

*Taussig, Siegmund. Die Hundskrankheit (endemischer Magenkatarrh) in der Herzegowina. In Wiener Klin. Wchnschr., v. 18, no. 7, p. 163. Vienna, Feb. 16, 1905.

Mention of Kriebemucken (Simuliidæ). This name is applied here erroneously to the "Papadatsche fly" which is a species of Psychoda.

*Taylor, T. H. On the tracheal system of Simulium. In Trans. Ent. Soc. London f. 1902, p. 701-716, 8 fig.

TÉglás, Gabor. A kolumbácsi légy Hunyad megyében. In Természettudomanyi Közlony, v. 12, p. 438-440, 1880.

*Theobald, Fred. V. An Account of British Flies, v. 1, 215 p., 44 fig., 4 pl. London, 1892.

Pages 5, 15, 20, 165, 168. Simulidæ-list of species and synonymy. Fig. 36, S. reptans.

*Theobald, Fred. V. Report on a collection of mosquitoes and other flies from Equatorial East Africa and the Nile Provinces of Uganda. In Reports of the Sleeping Sickness Commision, Royal Society, no. 3, p. 33-42. London, 1903.

Töмösváry ÖDöN. Die Kolumbaczer Mücke. Im Auftrage des königl. ung. Ministeriums für Ackerbau, Industrie und Handel verfasst. 23 p., 1 pl. Ung.-Weisskirchen, 1885.

*TömösváRy, ÖDöN. A Simulia-fajok bábjának lélekzöszervei. In Rovartani Lapok, v. 1, no. 2, p. 34-37, 1 fig., Jan., 1884.

Figure of pupal filaments of $S$. columbaczense.

Tömösváry, ÖDöN. Golubacka muha. In Glasnik Hrvatskoga Naravoslovnoga Drustva, v. 6-8, p. 187-203. Zagreb, 1891-1896.

*Townsend, C. H. T. On a species of Simulium from the Grand Cañon of the Colorado. In Trans. Amer. Ent. Soc., v. 20, p. 45-48, 6 fig., 1893.

*Townsend, C. H. T. A new Simulium from Southern New Mexico. In Psyche, v. 6, no. 183, p. 106-107, July, 1891.

Description of new species, S. occidentale.

*Townsend, C. H. T. On the correlation of habit on Nemocerous and Brachycerous Diptera between the Aquatic larvæ and the blood-sucking females. In Jour. N. Y. Ent. Soc., v. 3, no. 3, p. 134-136, Sept., 1895.

*Ussing, HJ. Simulia-Mygegne. Kobenhaven Flora og Fauna 1910. p. 42-44. 1910.

On the Simuliidæ. (Danish.) 
*Verdat. Memoire pour servir à l'historie des Simulies genre d'insectes de l'ordre des Diptères, famille des Tipulaires; lu à la reunion de la Société helvetique des Sciences Naturelles à Bâle le 25 Juillet 1821. In Naturwiss. Anzeig. d. allg. schweiz. Gesellsch. 1822, Jahrg. 5, no. 9, p. 65-70, Tab. 1. (Thon. Archiv. 1830, v. 2, pt. 2, p. 66-69.)

*Volger. Die Tracheenkiemen der Simulien-Puppen. (For summary see J. R. Micr. Soc. 1887, p. 227.) In Mitt. Schweiz. Ent. Gesell. Bd. 7, Heft 7, p. 277-282, 4 fig., 1886.

*Wahlburg. Bidrag till kännedomen om Stickmyggorna och deras fiender. In Öfversigt af Kongl. Vetenskaps Akademiens Förhandlingar. Arg. 4, no. 9, p. 258. Stockholm, 1848.

Mention of "knott" (Simulia).

*WahlgREN, E. Über einige Zetterstedt'sche Nemocerentypen. In Arkiv. Zool., Bd. 2, no. 7, p. 17-19. Stockholm, 1904.

*Walker, Francis. List of the Specimens of Dipterous Insects in the Collection of the British Museum. 687 p., 1848.

Pages 110-113. Simulium; descriptions of new species, S. decorum and $S$. invenustum. Also list of other species in the British Museum.

*Washburn, F. L. Simuliidæ-Black flies, buffalo gnats. In Tenth Ann. Rpt. State Ent. Minn. f. 1905, p. 70-76, fig. 59-63, Dec., 1905.

With figures in text after Lugger.

*Webster, F. M. The overflow of the Mississippi River and its effect upon the species of Simulium (buffalo gnats) infesting the smaller inland streams of the adjacent country. In 4th and 5th Rpt. U. S. Dept. Agr., Bur. Anim. Indus., p. 156-165, 1887.

*Webster, F. M. Reports on buffalo gnats. U. S. Dept. Agr. Div. Ent. Bul. 14 [old series], p. 29-39, 1887.

*Webster, F. M. Buffalo gnats (Simuliidæ) in Indiana and Illinois. In Proc. Ind. Acad. Sci., p. 155-159, 1891.

*Webster, F. M. Observations on injurious and other insects of Arkansas and Texas. In Insect Life, v. 3, nos. 11-12, p. 451-455, Aug., 1891.

Reference to Simulium attacking stock.

*Webster, F. M., and Newell, Willion. Insects of the year in Ohio. U. S. Dept. Agr. Div. Ent. Bul. 31, p. 84-90, 1902.

*Webster, F. M. The suppression and control of the plague of buffalo gnats in the valley of the lower Mississippi River, and the relations thereto of the present levee system, irrigation in the arid West, and tile drainage in the middle West. In Proc. 25th Ann. Meeting Soc. Prom. Agr. Sci., p. 53-72, 3 fig. St. Louis, 1904.

Simulium pecuarum and S. meridionale. Three figures after Riley.

*Weed, C. M. An experiment with black flies. U. S. Dept. Agr. Div. Ent. Bul. 46, p. 108-109, 1904.

*Weed, C. M. Experiments in destroying black-flies. N. H. Col. Expt. Sta. Bul. 112, p. 133-136, 4 fig., 1904.

Simulium venustum.

*Weismann, August. Über die Entstehung des vollendeten Insekten in del Larve und Puppe. In Abhandlungen, Herausgegeben von der Senckenbergischen Naturforschen den Gesellschaft, Bd. 4, p. 227-261, pl. 10-11, 1862-1863.

Pages 249-254. Figures of tracheal system of larva and pupa. 
* Wellarax, F. C. Notes on some Angolan insects of economic or pathologic importance. In Ent. News, v. 19, no. 5, p. 224-230, May, 1908.

Page 227. Simulium damnosum in Africa.

*Wesché, W. The mouth-parts of the Nemocera and their relation to the other families in Diptera. In Jour. Roy. Micros. Soc., p. 28-47, pl. 3-8. London, 1904 .

*Westwood, J. O. The watercress fly. In Gard. Chron., no. 13, p. 204, Mar. $25,1848$.

*Wiedemaxx, C. R. W. Aussereuropaische Zweiflügelige Insecten. Bd. 1, p. 71, Hamm, 1828.

"Kriebelmücke." Simulia. S. venusta Say. Description after Say in German and Latin.

*Willistox, S. IT. List of Diptera of the Death Valley Expedition. In U. S. Dept. Agr. Bur. Biol. Surrey, no. 7 , pt. 2 (North American Fauna), p. 253-268, 1893.

Pages 253-254. Description of S. argus n. sp.

*Willistox, S. W. Diptera of St. Vincent. In Trans. Ent. Soc. London f. 1896, p. 253-308, 1896.

Pages 268-269. Description of S. tarsale n. sp.

*Williston, S. W. Biologia Centrali-Americana, Insecta Diptera, r. 1, p. 223$224,1900$.

Simuliidæ-S. argus.

*Wise, K. S. The Simulidæ of British Guiana. In Timehri: Jour. Royal Agr. Com. Soc. British Guiana, r. 1, ser. 3, p. 248-254, 1911.

Description of $S$. guianense $\mathrm{n}$. sp.

*Zetterstedt, J. W. Insecta Lapponica. 1139 p. Lipsiæ, 1840.

Pages 802-803. Fam. Simulides. Description of European species with previous references.

*Zetterstedt, J. W. Diptera Scandinaviæ, t. 9, p. 3414-3433. Lundæ, 1850.

Fam. Simulides. Revision of the family, and also important biological notes.

*...... Recent pellagra investigations by the British Pellagra Commission. (Under title of editorial.) In Jour. Trop. Med. London, v. 14, no. 24, p. 374-376, 1 fig., Dec. 15, 1911. 